\title{
The emergence of trophoblast cell-surface antigen 2 (TROP-2) as a novel cancer target
}

\author{
David M. Goldenberg ${ }^{1,2}$, Rhona Stein ${ }^{1}$ and Robert M. Sharkey ${ }^{1,3}$ \\ ${ }^{1}$ Center for Molecular Medicine and Immunology, Belleville, NJ, USA \\ ${ }^{2}$ IBC Pharmaceuticals, Inc., Morris Plains, NJ, USA \\ ${ }^{3}$ Immunomedics, Inc., Morris Plains, NJ, USA \\ Correspondence to: David M. Goldenberg, email: dmg.gscancer@att.net \\ Keywords: TROP-2; TACSTD2; sacituzumab govitecan; antibody-drug conjugates; immunotherapy \\ Received: April 30, $2018 \quad$ Accepted: May 31, $2018 \quad$ Published: June 22, 2018 \\ Copyright: Goldenberg et al. This is an open-access article distributed under the terms of the Creative Commons Attribution Li- \\ cense 3.0 (CC BY 3.0), which permits unrestricted use, distribution, and reproduction in any medium, provided the original author \\ and source are credited.
}

\section{ABSTRACT}

TROP-2 is a glycoprotein first described as a surface marker of trophoblast cells, but subsequently shown to be increased in many solid cancers, with lower expression in certain normal tissues. It regulates cancer growth, invasion and spread by several signaling pathways, and has a role in stem cell biology and other diseases. This review summarizes TROP-2's properties, especially in cancer, and particularly its role as a target for antibody-drug conjugates (ADC) or immunotherapy. When the irinotecan metabolite, SN-38, is conjugated to a humanized anti-TROP-2 antibody (sacituzumab govitecan), it shows potent broad anticancer activity in human cancer xenografts and in patients with advanced triple-negative breast, non-small cell and small-cell lung, as well as urothelial cancers.

\section{INTRODUCTION}

The challenge of cancer treatment remains selectivity - attacking the cancer while minimizing collateral damage to normal cells. Since cancer cells are altered in some fundamental way, it is logical to think that these differences are manifested by genetic changes and/ or the expression of new protein molecules. If accessible, these can serve as therapeutic targets providing tumor specificity. Indeed, these considerations led to the era of targeted cancer therapies, which include agents that block the growth and spread of cancer by interfering with specific molecules critical to the features of malignancy, such as proliferation, progression, and spread; hence, the development of molecularly-targeted drugs, more generally comprising what is termed precision medicine.

Precision medicine now represents the focus of most anticancer therapies in development, based on the identification of targetable gene mutations and marker proteins that lead to more selective methods of prevention, diagnosis and therapy [1]. For example, the BCR-ABL fusion protein made from two different genes was found to promote the proliferation of leukemic cells, thus proving to be a useful therapeutic target (imatinib mesylate) [2, 3]. However, even before the era of precision medicine, many proteins produced in elevated quantities by tumor cells, such as Bence-Jones protein, beta human chorionic gonadotrophin ( $\beta$-HCG), alpha-fetoprotein (AFP), carcinoembryonic antigen (CEA), prostatic acid phosphatase, and human epidermal growth factor receptor (EGFR), and EGFR-2 (HER2), were used as circulating biomarkers of disease activity aiding in immunodiagnosis [4] or even as targets for radionuclide- or drug-conjugated antibodies [5, 6].

This review focuses on TROP-2, which is increased in a large variety of solid cancer cells and appears, both as a gene and protein, to affect signaling pathways involved in cancer proliferation, migration, invasion, and metastasis. Its role as a biomarker for cancer therapeutics also is addressed.

\section{DISCOVERY OF TROP-2}

Although first described almost 40 years ago as a cell surface marker of trophoblast cells [7], TROP-2 (trophoblast cell-surface antigen 2) was rediscovered in ensuing years as tumor-associated calcium signal transducer 2 (TACSTD2), membrane component 
chromosome 1 surface marker 1 (M1S1), gastrointestinal antigen 733-1 (GA733-1), and epithelial glycoprotein-1 (EGP-1) $[8,9]$.

The expression, role, and function of TROP2 became of interest to us in about 1990, when we developed a monoclonal antibody that reacted with a glycoprotein expressed by many different cancer types. In our initial reports we referred to this as EGP-1 [10-13]. The recognition that this antibody recognized a unique marker of trophoblast and neoplastic cells, [renamed TROP-2 once it was identified as the same antigen called by different designations [10-12]], was fortuitous, because it was developed in the search of a marker of non-small-cell lung cancer (NSCLC) $[10,11]$. The murine monoclonal antibody, designated RS7-3G11 (later shortened to RS7), was developed by immunizing mice with a cell membrane preparation isolated from a surgical specimen of a squamous NSCLC. RS7 bound strongly to lung, breast, and prostate cancer cell lines, weakly to colon cancer cell lines, and was absent in a lung fibroblast cell line, as well as granulocytes, monocytes and lymphocytes. Immunohistology of fresh frozen tissues showed that RS7 bound to breast, colon, renal, lung, and prostate cancers (33/40 [83\%] positive, with $22 / 33$ [67\%] staining strongly positive). Weak staining also was observed in 16/20 normal tissues from the breast, colon, kidney, liver, lung, and prostate $[10,11]$.

The molecular properties of the antigen bound by RS7 were identified in 1993 (11), when the EGP-1 antigen was described as a $46-\mathrm{kDa}$ glycoprotein $(35 \mathrm{kDa}$ when deglycosylated) [12-14] that was phosphorylated by protein kinase $\mathrm{C}$ (PKC), this occurring specifically on serine 303 in the cytoplasmic domain [14]. This suggested that TROP-2 has a role in signal transduction across the cell membrane. Particularly interesting was the observation that $50 \%$ the RS7 antibody bound to the cell surface internalized within $\sim 1 \mathrm{~h}[11,15]$.

Early studies recognized that TROP-2 is involved in regulating cancer growth and invasion [7, 16, 17]. The gene, TACSTD2, was mapped on chromosome $1 \mathrm{p} 32$ [18]. The $36-\mathrm{kDa}$ nascent polypeptide, which is posttranslationally modified by N-linked glycosylation, forms a type- 1 transmembrane protein that is distinct from its sister molecule, epithelial cell adhesion molecule (EpCAM or EGP-2) [11-13].

\section{TROP-2 PROPERTIES AND FUNCTIONS}

The TROP-2/TACSTD2 gene has been sequenced in several mammalian species [19-21]. Its intronless gene encodes a 35-46-kDa protein having 323 amino acids, comprised of a large extracellular domain, a single transmembrane domain, and a short intracellular, or cytoplasmic tail (Figure 1) [14, 16, 22]. It encodes a transmembrane $\mathrm{Ca}^{++}$-signal transducer $[14,23]$. The single transmembrane region of TROP-2 has 23 amino acids and a 26-amino acid cytoplasmic region (Figure 1) [22]. The cytoplasmic tail shows structural and sequence homology to a HIKE domain [24-26] and, as described, contains a serine residue (S303) that is phosphorylated by PKC [14], as well as a phosphatidyl-inositol 4,5-bisphosphate $\left(\mathrm{PIP}_{2}\right)$ binding site [27]. The signaling peptide of TROP-2 protein in the cytoplasmic tail is composed of 30 amino acids; the extracellular domain has 244 amino acids, with 12 cysteine residues [22]. There is a thyroglobulin type 1 repeat domain $[19,28]$, and upstream from this is an epidermal growth factor-like domain [19, 28].

TROP-2 can affect signaling by insulin-like growth factor-1 (IGF-1) [29], and by interaction with neuregulin 1, inhibits ErbB3 (HER3) in head and neck squamous cell cancer [30]. Having a HIKE domain and a $\mathrm{PIP}_{2}$ binding site, as well as the serine phosphorylated by PKC, indicate that TROP-2 is involved in calcium signaling. This $\mathrm{Ca}^{2+}$ release is thought to induce mitogen-activated protein kinase (MAPK) signaling and advance the cell cycle [31]. The phosphorylation of TROP-2 by increased PKC could in turn activate the Raf and NF-KB pathways [8] (Figure 2).

The TACSTD gene family also contains the gene that codes for Trop-1, also known as gastrointestinal antigen 2 (GA733-2), EGP-2 (12), or EpCAM. Although EpCAM is coded by a different gene on chromosome $2 \mathrm{p} 21$, it shares $49 \%$ sequence identity and $67 \%$ sequence similarity with TROP-2; EpCAM has 314 amino acids and is a $35 \mathrm{kDa}$ protein $[19,32]$. They are both type I transmembrane proteins, but unlike TROP-2 that is intronless, EPCAM has nine coding exons; $1-6$ code for the extracellular domain, while exon 7 is the transmembrane domain and exons 8-9 code for the intracellular region [33].

TROP-2 and EpCAM have similar cysteine positions and distributions of hydrophilic and hydrophobic residues, but EpCAM only has three $\mathrm{N}$-glycosylation sites in contrast to four for TROP-2 [34]. There are also differences in the intracellular tails that account for different intracellular signaling and thus different functions and distributions between TROP-2 and EpCAM. The highest homology is in the thyroglobulin repeat and the single transmembrane domains $[19,20]$. The promotor regions of EPCAM and TROP-2 are unrelated, resulting in different expression patterns [35].

TROP-2 has been reported to bind to several proteins, such as IGF-1, claudin-1 and -7 , cyclin D1, and PKC (Figure 2). At least IGF-1 could be a ligand for TROP-2, modulating IGF-1 signaling and activating $\mathrm{PIP}_{2}$ and $\mathrm{Ca}^{2+}$. TROP-2 may also complex with IGF-1, presumably blocking IGF-1 signaling [29]. In contrast to the experience with most cancers, high expression of TROP-2 suppresses lung cancer growth by attenuating IGF-1R signaling, probably by complexing with IGF1 [36]. Claudin-1 and -7 are transmembrane proteins that bind to TROP-2's ectodomain, which may affect maintaining tight junctions at the epithelial surface, possibly preventing claudin degradation [36]. 
TROP-2 also activates the ERK1/2 (extracellular signal regulated kinase)-MAPK pathways, contributing to cell progression [29], and could play a role in deregulating stem cell functions via Notch, Hedgehog and Wnt pathways (Figure 2) [31]. As mentioned, the MAPK pathway is also stimulated when $\mathrm{Ca}^{2+}$ is increased. Thus, TROP-2 generally increases the levels of phosphorylated MAPK, affecting cell cycle progression. Further, activation of ERK has been reported in several tumor types that overexpress TROP-2, and this ERK1/2 activation is thought to promote tumor survival by having anti-apoptotic effects [31].

\section{TROP-2 IN CANCER}

TROP-2 has been studied in embryonic and fetal development [20], but most studies have focused on its role in cancer. As mentioned, with rare exceptions, it has been linked to increased tumor growth and enhanced proliferation, cell migration and anchorage-independent growth, and is overexpressed in most human solid epithelial cancers, such as oral, head-and-neck, thyroid, lung, esophageal, gastric, colorectal, pancreatic, breast, renal, uterine, cervical, ovarian cancers, and glioma [3750]. These authors proposed that TROP-2 is a prognostic marker in most of these cancers (reviewed in [38]). The ectopic production of TROP-2 in cancer cells in culture has been shown to transform murine fibroblasts when injected into mice, suggesting at first that TROP-2 is an oncogene [51]. Further studies modified this view [52], so that although the level of TROP-2 generally influences malignancy, it may not by itself be a true oncogene.
Nevertheless, knockdown of the TROP-2 gene by smallinterfering (si) RNA in colon, breast, cervical, lung, and ovarian cancer cells inhibits their proliferation, invasion, and the formation of colonies in vitro [43, 51, 53-55]. The knockdown of TROP-2 in gallbladder cancer reduces cell proliferation, invasion and migration, but also inhibits vimentin and increases E-cadherin expression linked to epithelial-mesenchymal transition (EMT) [56].

Tumor growth in mice is related to levels of TROP2 mRNA, where high expression of TROP-2 is found in the largest tumors [53]. Inhibition of TROP-2 with antiTROP-2 antibodies decreases migration of colon and breast cancer cells in vitro $[51,57]$, while overexpression increases the migration of pancreatic cancer cells [31]. High TROP-2 expression is also correlated with increased metastasis in patients with different cancer types (oral squamous, thyroid, some esophageal, gastric, colorectal, pancreatic, ovarian, uterine, cervical, prostate, and urinary bladder), but is not upregulated in others (e.g., head and neck and certain lung cancers, such as lung adenosquamous and squamous cell carcinoma histology) (reviewed by $[9,37,38,58]$ ). In gastric cancer, there appears to be a relationship between increased TROP-2 and amphiregulin coexpression and poor survival [59]. In HNSCC, TROP-2's gene (TACSTD2) has been identified as the target of microRNA, miR-125-1, resulting in dysfunction of the MAPK pathway [60]. The effects of TNF- $\alpha$ on regulation of TROP- 2 expression in colon cancer indicated that low concentrations increase TROP-2 protein expression, while higher concentrations of TNF- $\alpha$ have a decreasing influence [61]. These authors also related TNF- $\alpha$ stimulation to the ERK1/2 pathway, because

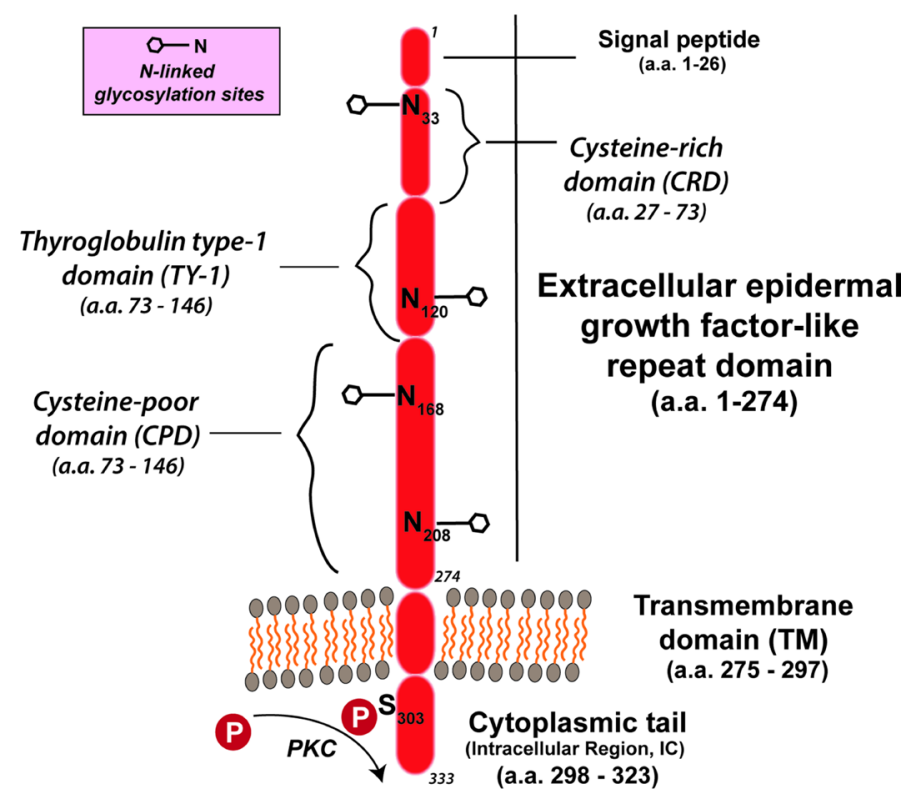

Figure 1: TROP-2 structure [as per Vidmar et al. [36]]. TROP-2 contains a 274-amino-acid extracellular epidermal growth factor-like repeat portion that contains 3 domains, a cysteine-rich domain, a thyroglobulin type-1 domain, and a cysteine-poor domain. The molecule traverses the membrane and terminates with a cytoplasmic tail that has a serine at position 303 that can be phosphorylated. The molecule has $4 \mathrm{~N}$-glycosylation sites in the extracellular domain. 
a specific inhibitor of ERK1/2 suppresses the cytokine's upregulation of TROP-2 [61]. However, the role of TROP2 in hematological tumors is unclear, being expressed in Hodgkin lymphoma and chronic lymphocytic leukemia [9], but not in anaplastic large cell lymphoma [62].

From a functional perspective, it is important that TROP-2 fuses with cyclin D1 (bicistronic cyclin D1TROP-2) to become an oncogene [63]. This binding of the two mRNA molecules affects the stability of cyclin $D 1$, and as a chimera, can increase cell longevity and proliferation [8], as well as transformation. Indeed, tumor growth can be inhibited by silencing this fusion protein [29]. In invasive ductal breast cancer, elevated expression of TACSTD2 and cyclin D1 at the mRNA and protein levels were shown to be independent prognosticators of a poor outcome [42].

Although both TROP-2 and EpCAM predict a poor prognosis when overexpressed in breast and ovarian cancers, in small-sized adenocarcinoma they have opposite biological effects, with TROP-2 having a negative prognostic effect while EpCAM indicating a favorable prognosis [64]. From an evolutionary perspective, EpCAM is believed to have

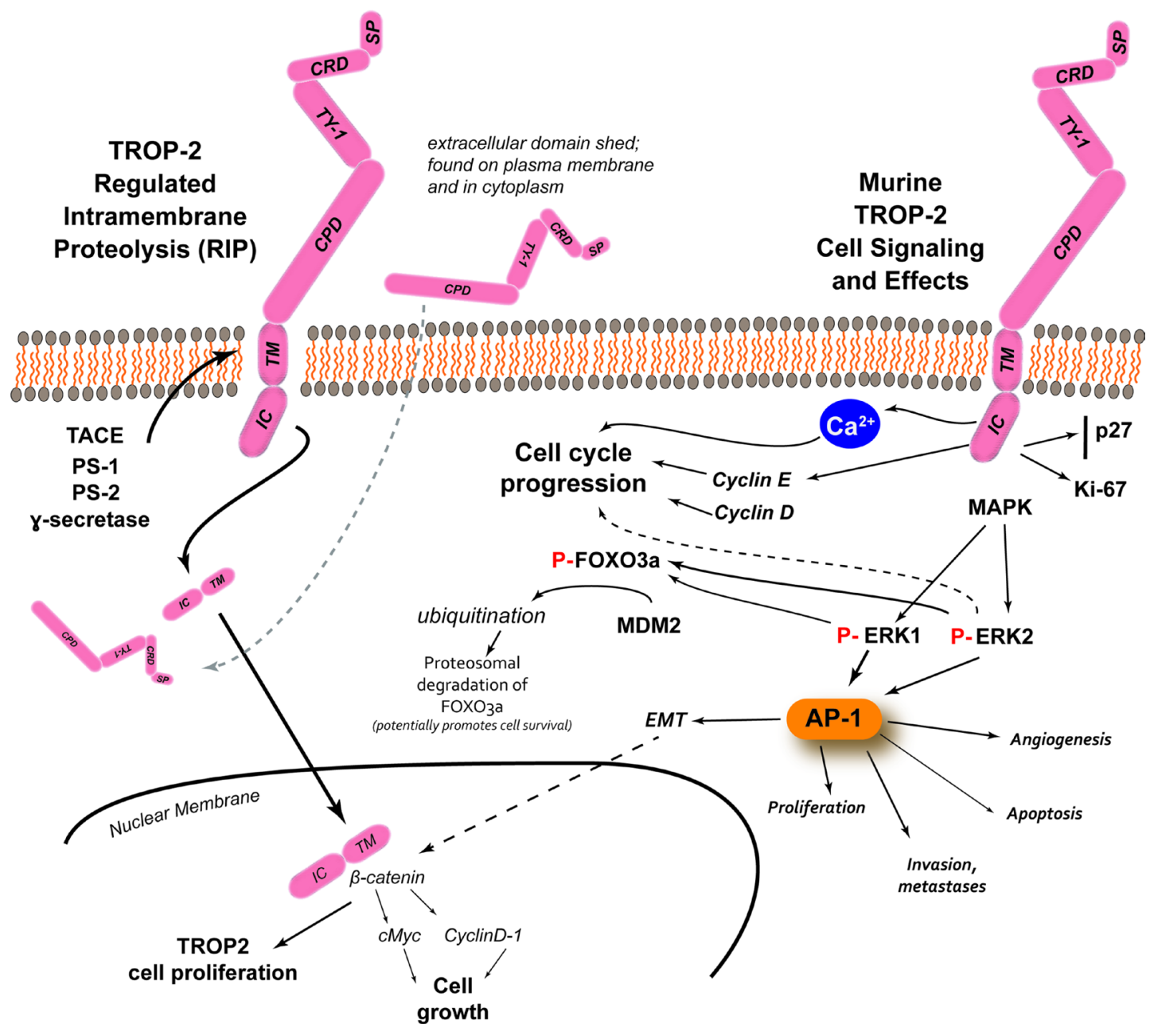

Figure 2: TROP-2 processing, cell signaling and its effects [adapted from Shvartsur and Bonavida, [9]]. In prostate cancer, studies have found several enzymes involved in the cleavage of the TM-IC portion of the molecule, with the extracellular domain remaining associated with the plasma membrane or found in the cytoplasm. $\beta$-catenin colocalized with TM-IC in the nucleus, which can lead to TROP-2-driven proliferation, but also it can upregulate cyclin D1 and c-myc, which can lead to cell growth. Apart from its processing, TROP-2 has the potential to influence several intracellular signaling pathways that can then lead to several different events. The phosphorylation of serine-303 appears be involved in the release intracellular $\mathrm{Ca}^{2+}$, which can activate Raf and NF- $\mathrm{kB}$ pathways, and stimulate MAPK signaling and cell cycle progression. TROP-2 can increase cyclin D1 and cyclin E, which together with ERK1/2 can mediate cell cycle progression. Studies with murine TROP-2 have revealed the stimulation of MAPK and downstream upregulation of phosphorylated ERK1/2 can induce the AP-1 transcription factor that can regulate a number of tumor-associated target genes involved in angiogenesis (e.g., via VEGF), proliferation (e.g., via cyclins and CDKs), apoptosis (e.g., via BCL-2, FasL), and invasion and metastasis (e.g., via matrix metalloproteinases, podoplanin, Ezrin, and CD33), as well as epithelial to mesenchymal transition (EMT) that can interact with $\beta$-catenin to affect cell growth. Studies with murine TROP-2 also found that increased ERK activity can induce the phosphorylation of FOXO3a, followed by its ubiquitination by mouse double minute 2 (MDM2), with its subsequent degradation. The degradation of FOXO3a can promote cancer cell survival. 
given rise to $T R O P-2$ by retroposition prior to the divergence of avian and mammalian lineages [19].

Summarizing, the increased expression of TROP-2 is reported to be "necessary and sufficient" for stimulation of cancer growth, while a bicistronic cyclin D1/TROP2 mRNA chimera is an oncogene [53, 65]. Importantly, elevated expression is associated with more aggressive disease and a poor prognosis in several cancer types $[8$, $9,20,37-50,66]$. This elevated tumor expression of TROP-2 does not appear to circulate in the blood, yet there is a report that some esophageal cancer patients have circulating antibody to this biomarker [67]. There are at least six major signaling pathways involving TROP-2 in cell proliferation, but its precise role in these and which pathway(s) are critical in different cancers and in different therapeutic approaches remain to be elucidated.

The TROP-2 signaling network involved in cancer proliferation has been studied extensively by Alberti and coworkers [23, 27, 41, 53], and reviewed recently by Shvartsur and Bonavida [9]. These authors have also reviewed the TACSTD2 transcription control network, indicating that the TROP-2 gene is connected with many transcription factors. Importantly, TROP-2 upregulation activates CREB1 (cyclic AMP-responsive-element binding protein), Jun, NFKB, Rb, STAT1 and STAT3 via induction of the cyclin D1 and ERK/MEK pathways [41].

\section{TROP-2 IN STEM CELL BIOLOGY AND OTHER DISEASES}

TROP-2 has also been found in stem cells of various tissues, particularly in basal cells. For example, in murine and human prostate, the basal cells expressing TROP2 have self-renewal, regeneration and differentiation properties [68, 69]. After liver injury, undifferentiated oval cells express TROP-2 [70]. Endometrial-regenerating cells also express TROP-2 [71]. These findings support the view that TROP-2 may be implicated in the regulation of stem cell growth and regeneration in several tissues, perhaps playing a role in increased cell proliferation, such as hyperplasia.

Studies in the prostate reveal a potential role of TROP-2 in oncogenesis. The normal prostate is composed of three primary cell types: luminal, basal, and neuroendocrine. The luminal cells express the secretory proteins, such as prostate-specific antigen (PSA) and cytokeratin-8, and high levels of androgen receptor, while the basal cells are below and express other markers and less androgen receptor. The luminal cells have been considered to be precursors of adenocarcinoma, but Goldstein et al. showed that basal cells expressing TROP2 can form prostate carcinoma in immunodeficient mice [69]. Thus, basal cells expressing TROP-2 and CD44 can transform to tumors of the luminal phenotype $[68,69,72$, 73]. This is consistent with studies implicating TROP-2 as a key regulator of $\beta 1$ integrin activities and promoting prostate cancer cell motility $[74,75]$. Interestingly, TROP$2^{+}$exosomes purified from prostate cancer promote migration of TROP-2-negative prostate cancer cells on fibronectin, suggesting that TROP-2 could induce cells lacking TROP-2 to gain TROP-2 regulatory properties affecting migration [47].

TROP-2 also has been implicated in stem cell changes in cardiomyopathy and pulmonary disease. It was demonstrated in mice that although $\mathrm{c}-\mathrm{kit}^{+} / \mathrm{TROP}-$ $2^{+}$cells are rarely expressed by normal myocardium, their frequency increases significantly following the induction of a myocardial infarct [76]. Evidently these putative stem cells participate in proliferation and survival following this wound, leading to activation of the MAPK cascade via TROP-2-induced signal transduction, similar to oncogenesis. Thus, activation of TROP-2 could provide protection to the damaged myocardium by promoting proliferation of c-kit ${ }^{+}$stem cells.

It has also been reported that increased expression of TROP-2 in airway basal cells could contribute to proliferation of such cells derived from smokers with chronic obstructive pulmonary disease (COPD) [77]. TROP-2 basal cells exhibit improved proliferation with activation of the ERK1/2 phosphorylation signaling pathway, and with an EMT-like change, not unlike the effects found in oncology. Down-regulation of TROP-2 by siRNA significantly reduces the proliferation of basal cells from these COPD patients, mitigating the EMT-like features. These changes may also be implicated in the genesis of squamous cancer in smokers, where TROP-2 is also a targetable therapeutic marker.

\section{TACSTD2 MUTATION CAUSES GELATINOUS DROP-LIKE CORNEAL DYSTROPHY (GDLD)}

In 1999, Tsujikawa et al. [78] identified an inherited mutation in the TROP-2 gene, TACSTD2, as the cause of GDLD, which was first recognized as an autosomal recessive disease leading to the development of severe corneal amyloidosis and blindness in Japanese in 1914 by Nakaizumi [79], but later also identified in other nationalities [80], including other mutations of TACSTD2 [80]. The most frequent mutation [ $82.5 \%$ of all mutations of this gene in Japanese] [78] involves glutamine being replaced with a stop codon, Q118X, at codon 118, in the thyroglobulin repeat domain. The result is a truncated protein lacking the transmembrane domain, with a decrease or absence of certain tight junction proteins, including claudin 1,4 , and 7 [81, 82]. This results in lactoferrin penetrating the corneal epithelium and the onset of amyloidosis, causing blindness [82]. This role of TROP-2 in barrier function and tight junction is likely also related to its effects on the adhesion and migration of cancer cells. However, no mutations in TACSTD2 have been reported in cancer. 


\section{CANCER THERAPIES TARGETING TROP-2}

\section{Radioimmunotherapy}

Radioiodinated RS7 targets human cancer cell line xenografts selectively and specifically $[10,15,83,84]$, but its internalization properties influenced the selection of radionuclide; i.e., residualizing radioiodine or radiometals (e.g., ${ }^{111} \mathrm{In} /{ }^{90} \mathrm{Y}$ ) increase tumor accretion and improve efficacy [83, 85-89].

Interestingly, despite internalization, TROP-2 is an appropriate target for a two-step pretargeting approach, using a bispecific antibody with one arm targeting TROP2 and another arm binding a hapten of 3 amino acids [9093]. Since a pretargeting method relies on the retention of the bispecific antibody on the cell surface, there was concern that an internalizing anti-TROP-2 antibody would not be an ideal first targeting agent because of a short residence time on the tumor cell surface. However, even after a delay of about one day, in vitro studies showed that a sufficient amount of the bispecific antibody remains on the cell surface to permit subsequent targeting by the radiolabeled hapten [90]. Hence, the 2-step pretargeting approach with TROP-2 can provide excellent imaging and therapeutic results using a radiolabeled hapten [84, 90-92].

\section{Other TROP-2-targeted therapeutics}

Unlike radionuclides that can exert a therapeutic effect without requiring internalization because of a crossfire effect, other cytotoxic agents, such as drugs and toxins, require internalization and processing within the cell to exert the desired effects. Thus, the internalization properties of the RS7 antibody targeting TROP-2 provide opportunities for the delivery of cytotoxic compounds to cancers expressing TROP-2. For example, Chang et al. [94] first reported the development of a recombinant fusion protein between the humanized version of the RS7 antibody (hRS7), where a deglycosylated mutant form of the RNase toxin, Rap (Rana pipiens) was fused to the N-terminus (i.e., on the $\mathrm{V}_{\mathrm{L}}$ ) of the light chains, giving a substitution ratio of $2 \mathrm{Rap} / \mathrm{IgG}$. Liu et al. [95] subsequently reported the development of a unique set of fusion proteins, utilizing the Dock-and-Lock ${ }^{\circledR}\left(\mathrm{DNL}^{\circledR}\right)$ procedure [96-98] that paired the targeting of TROP-2 using the hRS7 IgG with the cytotoxic activity of Rap. Two agents were prepared, one with 4 Rap molecules attached to the $\mathrm{C}_{\mathrm{H}} 3$ heavy chain of the IgG and the other attaching 4 Rap molecules to the $\mathrm{C}_{\mathrm{K}}$ light chain. These constructs were tested primarily in triple-negative breast cancer (TNBC) cell lines, where they showed higher potency than the previously-described recombinant construct [94], with $\mathrm{EC}_{50}$ values in the subnanomolar level against several cancer cell lines [95]. In xenograft models, superior therapeutic responses also were reported [94].

\section{ANTIBODY-DRUG CONJUGATES (ADCS)}

This section focuses on two anti-TROP-2 ADCs that have been studied clinically, sacituzumab govitecan, using the topoisomerase inhibitor, SN-38 (an irinotecan metabolite) [66, 99-107], and another agent, RN927C, coupled to a derivative of the microtubule inhibitor, auristatin [108, 109]. Other TROP-2-targeted therapeutics have been described preclinically, one using a nanoparticle (carboxymethyl dextran) carrier linked with doxorubicin, which has activity in the MDA-MB-231 breast cancer cell line representative of TNBC [110], and another, utilizing doxorubicin conjugated to an anti-TROP-2 Fab, with activity in vitro and in vivo against pancreatic cancer [111].

\section{Sacituzumab govitecan (IMMU-132)}

The significant challenge for any ADC is the chemistry linking the drug to the antibody. Moon et al. [112] focused on evaluations of six linker-SN-38 derivatives that were bound through various modifications of the 20th position of SN-38's lactone ring, using as many as 5 antibodies with specificities for antigens found in hematopoietic and solid tumors. After consideration of challenges in chemistry, solubility, yields, retention of SN-38 potency and antibody binding, stability of the conjugate in buffer and serum, and, finally, activity when administered to nude mice bearing appropriate human cancer xenografts, cross-linked (CL) derivatives, designated CL2-SN-38 and CL2-SN-38(Et), were studied. In each case, 5-7 SN-38 moieties were coupled to the antibodies without compromising antibody binding to their respective antigen. After extensive in vitro and in vivo testing, the CL2 linker was selected (Figure 3), but with a further modification that eliminated the cathepsin-B cleavable Phe-Lys peptide, making the derivative known as CL2A the preferred linker for clinical use [99].

The next question was whether the therapeutic benefits of this type of conjugate are driven by the selectivity of the antibody or perhaps merely a slow release of the SN-38. In non-clinical studies, sacituzumab govitecan was tested against human epithelial cancer xenograft models of various gastrointestinal cancers, including gastric and pancreatic cancers, lung cancers, non-TNBC and TNBC, prostate, and cervical cancers [66, 99, 100]. Comparisons included SN-38, irinotecan (IRI), or a non-targeting ADC, with sacituzumab govitecan providing improved therapeutic outcomes in nearly every model studied. However, in vitro evidence of therapeutic selectivity based on the antibody binding was lacking, because the cytotoxicity assay used most commonly relied on an extended exposure (e.g., for 4 days) to the drug $[66,99,100]$. Since the SN-38 is released from the conjugate during this incubation period, specificity could not be demonstrated. Ultimately, an assay monitoring the formation of double-stranded DNA breaks showed 
definitively that a conjugate with the TROP-2 antibody enhanced DNA damage [66].

As mentioned above, in vivo testing illustrated a selective improvement in therapeutic responses attributed to the TROP-2 conjugate, but with the notable exception of the SK-MES-1 lung cancer cell line (derived from squamous cell carcinoma), where the therapeutic effects of sacituzumab govitecan are not significantly different from IRI. We reported [99] that TROP-2 expression, as determined by flow cytometry median fluorescence intensity, is lower in these cells than most of the other cancer lines tested. However, this cell line is also less sensitive to SN-38. Thus, while it is logical to expect efficacy to be driven by the expression level of a given antigen, there are other factors to consider, such as a tumor's sensitivity to the drug being used, and other physiological issues that might affect the delivery of the conjugate/drug to tumors in vivo.

In an effort to isolate how antigen expression might impact the in vivo efficacy of sacituzumab govitecan, cDNA of human TROP-2 was transfected into the MDAMB-231 TNBC cell line, which only expresses $\sim 32,000$ copies of membrane-bound TROP-2 per cell, in order to develop clones with increased expression [113]. Unlike SK-MES-1, where sacituzumab govitecan and IRI have a similar therapeutic benefit, MDA-MB-231 is unresponsive to either agent [113], and therefore it was of further interest to determine whether enhancement of TROP-2 expression yields improved selective sensitivity to sacituzumab govitecan. The results clearly indicate that $(i)$ transfection of the MDA-MB-231 with human TROP-2 cDNA does not appreciable alter its sensitivity to IRI, and (ii) increasing TROP-2 expression $\sim 4$ fold (from $\sim 30,000$ to $120,000)$ significantly enhances sacituzumab govitecan's therapeutic activity. This enhancement is clearly driven by the TROP-2 specificity of the ADC, since responses to a non-targeting ADC are not substantially different between the parental and transfected cells.

A final important consideration for an ADC is minimizing collateral damage to normal tissues, whether a consequence of the release of the drug or a result of its selective targeting to the antigen on normal cells (ontarget non-specificity). Given TROP-2's expression in a number of normal tissues, a study was performed in Cynomolgus monkeys who express TROP-2 in similar tissues as humans. At the highest dose of sacituzumab govitecan tested, the monkeys experienced severe neutropenia and diarrhea, typical symptoms for SN-38/IRI toxicity. However, histological assessment of the tissues revealed most TROP-2-expressing tissues had minimal toxicity, with recovery by the end of study [99]. Thus, it appeared that there was SN-38-directed toxicity, but not selective toxicity based on TROP-2 targeting, with many of the TROP-2 expressing normal tissues having minimal damage. An assessment of the clearance properties of sacituzumab govitecan in the monkeys revealed that the agent released the SN-38 payload at a similar rate as predicted from in vitro serum stability studies, while the IgG had a more protracted clearance.

Another line of nonclinical investigation was undertaken to confirm the improved delivery of SN-38 via the anti-TROP-2 antibody, compared to IRI. Sharkey et al. [114], using two human tumor xenografts, reported that the concentrations of $\mathrm{SN}-38$ in tumor xenografts showed a 20- to 136-fold improvement for the ADC vs. IRI. This clearly demonstrated the advantage of using the TROP-2-targeting antibody to deliver the topoisomerase1 -inhibiting drug. They also reported that levels of glucuronidated SN-38 (SN-38G) in the animals' serum were much lower with the ADC. SN-38G is a detoxified derivative of $\mathrm{SN}-38$; however, it recycles via the enterohepatic pathway, where it can then be converted to SN-38 by bacterial enzymes in the intestine, leading to late diarrhea in IRI therapy. The lower levels of SN-38G found with the ADC suggested severe diarrhea may be reduced. Thus, these results provided the impetus to pursue clinical studies with sacituzumab govitecan.

\section{Clinical trials with sacituzumab govitecan}

The Phase I clinical study with sacituzumab govitecan was designed as a basket trial including patients

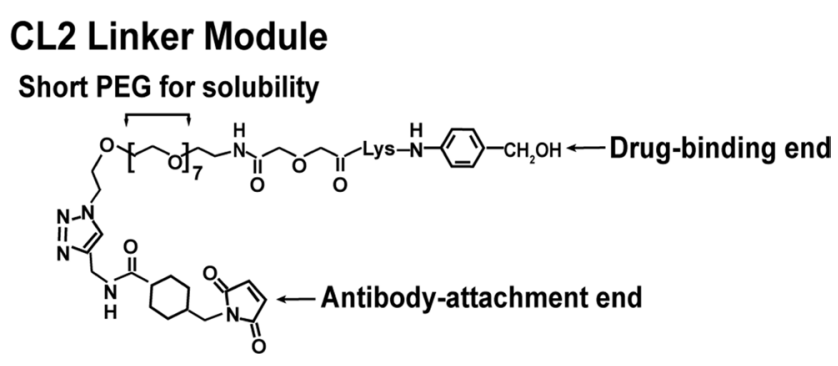

Figure 3: Representation of structure of the CL2A linker used to bind SN-38 to the anti-TROP-2 IgG to form sacituzumab govitecan. The CL2A linker forms a water-soluble SN-38 conjugate with excellent yields. Water solubility is achieved by inserting a short polyethylene glycol segment. The linker binds to the 20th position of SN-38, forming a pH-sensitive carbonate bond. Binding to the 20th position stabilizes the lactone ring. A maleimide at the end of the linker will enable a stable thioether bond with sulfhydryl moieties formed after mild reduction of the antibody. This process will bind up to 8 moieties to the antibody without affecting antigen binding. 
with diverse metastatic epithelial cancers who had failed conventional treatments, with 10 indications studied initially (i.e., colorectal [CRC], gastric, hepatocellular, non-small-cell [NSCLC] and small-cell lung [SCLC], ovarian, pancreatic, prostate, TNBC, and urothelial cancers [UC]) [101]. Prescreening for TROP-2 expression was not required, since immunohistology studies using tissue microarrays of these cancers indicated a higher than $80 \%$ positivity, with most having moderate to strong staining (Figure 4). As mentioned, TROP-2 is reported as a prognostic marker for most solid cancers (reviewed in [38]). At present, however, whether there is a difference in expression between primary and metastatic tumors has not been determined.

Patients were intended to receive multiple treatment cycles of sacituzumab govitecan, starting at a dose of $8 \mathrm{mg} / \mathrm{kg}$ given on days 1 and 8 of a 21 -day treatment cycle. Treatment continued until progression or when no longer tolerated. Dose delays of up to 2 weeks and dose reductions (e.g., by 25\%) were permitted. Responses were assessed every 8 weeks, with a confirmatory study performed within 4-6 weeks of any response, complying with RECIST 1.1 criteria for objective responses (114).

Gastrointestinal cancers represented the largest enrollment of the 25 patients included in this Phase I assessment, with $>30 \%$ tumor shrinkage found in 3 cases (SCLC, TNBC, and CRC). The maximum tolerated dose (MTD), based on the tolerance to the first treatment cycle, was determined to be $12 \mathrm{mg} / \mathrm{kg}$, with neutropenia as the dose-limiting toxicity. However, since the treatment was intended to be given over multiple cycles, and because it appeared that multiple cycles were tolerated better at the starting dose levels of 8 and $10 \mathrm{mg} / \mathrm{kg}$ [101], the Phase II portion of this basket trial was expanded first to include enrollment at each of these two dose levels.

Ocean et al. [115] reported an overview of the data from patients enrolled with diverse cancers, with 81 patients first given a starting dose of $8 \mathrm{mg} / \mathrm{kg}$, followed by enrollment of 97 given $10 \mathrm{mg} / \mathrm{kg}$. The study focused on evaluating safety and pharmacokinetics, with an initial examination of efficacy, based on overall response rate and clinical benefit rate, in 4 cancer indications having enrollment of more than 20 patients. The pharmacokinetics of the agent and its products (SN-38 and SN-38G) was similar at the 2 dose levels. As found in animal studies, levels of SN-38G in the serum were markedly less than that reported for IRI therapy $[116,117]$. An examination of safety, including the ability to tolerate sequential treatments at the starting dose level, showed the $8 \mathrm{mg} / \mathrm{kg}$ dose level was tolerated somewhat better, but the tolerance of $10 \mathrm{mg} / \mathrm{kg}$ dose level within the first cycle of treatment was acceptable. Dose delays or reductions were almost always based on neutropenia, which occurred at a similar rate as reported for IRI therapy, while cases of grade $\geq 3$ diarrhea was only $10 \%$ in the $10 \mathrm{mg} / \mathrm{kg}$ group, which was much lower than for IRI therapy. We speculated that lower

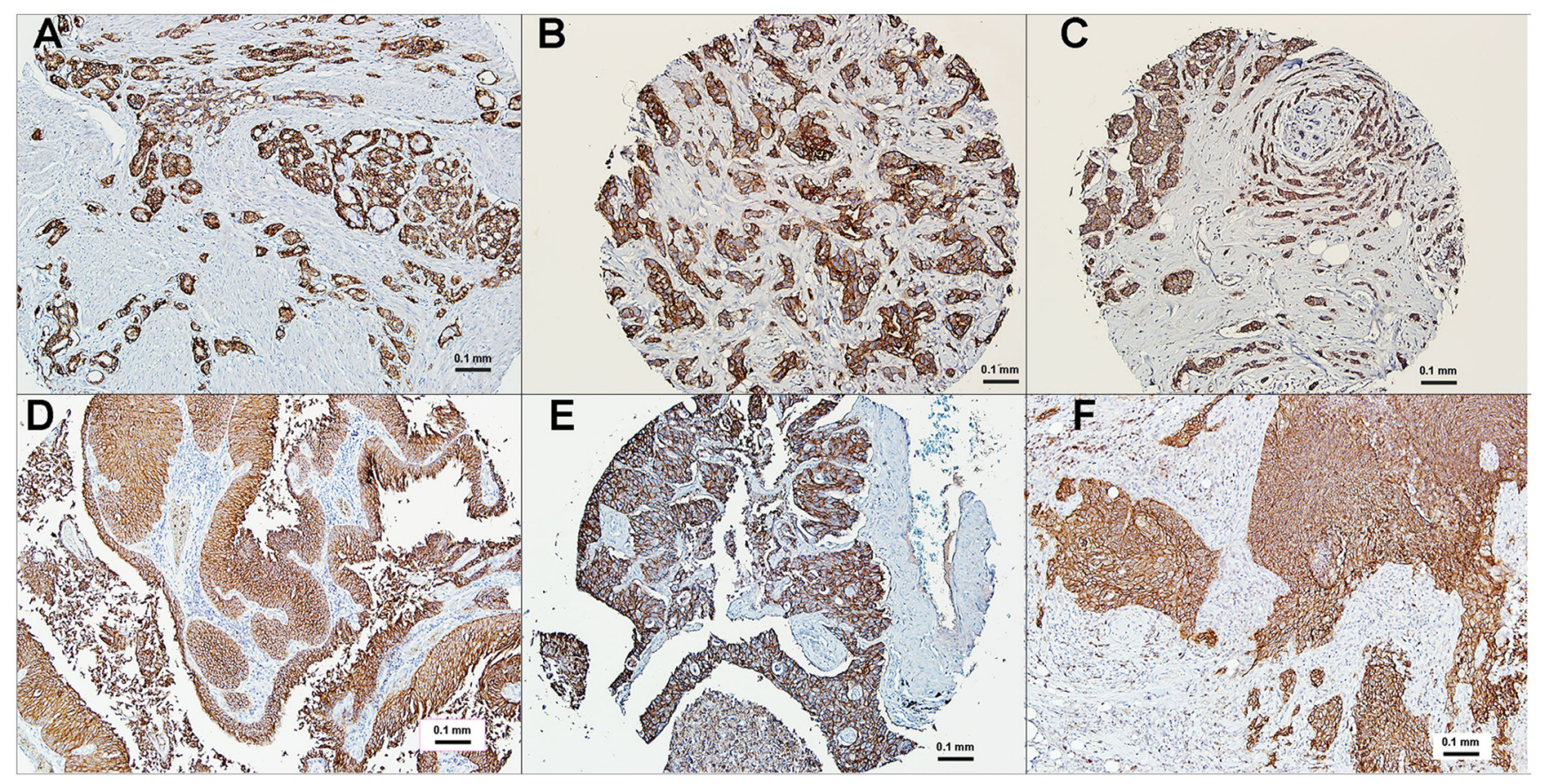

Figure 4: Immunohistochemical localization of TROP-2 in human cancers. Polyclonal antibody to human TROP-2 was used to reveal TROP-2 localization in tumor sections, mostly from commercial microarrays (bar $=0.1 \mathrm{~mm})$. (A) prostate cancer, $(\mathbf{B})$ triplenegative breast cancer, (C) estrogen-receptor and HER2 positive breast cancer, (D) urinary bladder cancer, (E) non-small-cell lung cancer, (F) small-cell lung cancer. All specimens selected based on their moderate (2+) to strong $(3+)$ expression of TROP-2. Staining is found both on the membrane and in the cytoplasm. 
Table 1: Summary of published results on phase II trials with sacituzumab govitecan

\begin{tabular}{|c|c|c|c|c|c|}
\hline $\begin{array}{l}\text { Cancer } \\
\text { type }^{1}[\text { Ref] }\end{array}$ & $\begin{array}{c}\text { Number of } \\
\text { patients }\end{array}$ & $\begin{array}{c}\text { Confirmed \% } \\
\text { ORR }^{2}\end{array}$ & $\begin{array}{c}\text { Median DoR } \\
\text { (months) }\end{array}$ & $\begin{array}{c}\text { Median PFS } \\
\text { (months) }^{3}\end{array}$ & $\begin{array}{c}\text { Median OS } \\
\text { (months) }^{3}\end{array}$ \\
\hline TNBC [106] & 69 & 30 & 8.9 & 6.0 & 16.6 \\
\hline $\mathrm{HR}^{+} / \mathrm{HER} 2^{-} \mathrm{BC}$ [135] & 54 & 31 & NR & NR & NR \\
\hline NSCLC [104] & 54 & 19 & 6.0 & 5.2 & 9.5 \\
\hline SCLC [103] & 50 & 14 & 5.7 & 3.7 & 7.5 \\
\hline $\mathrm{UC}$ [105] & 41 & 34 & 12.9 & 7.2 & 15.5 \\
\hline
\end{tabular}

${ }^{1} \mathrm{TNBC}$, triple-negative breast cancer; $\mathrm{HR}^{+} / \mathrm{HER} 2^{-} \mathrm{BC}$, hormone-receptor positive, HER2-negative metastatic breast cancer; NSCLC, non-small cell lung cancer; SCLC, small-cell lung cancer; UC, urothelial cancers.

$2 \%$ ORR, objective response rate $=($ complete response + partial response $) /$ number of patients.

${ }^{3} \mathrm{PFS}$, progression-free survival; OS, overall survival. Based on the number of intention-to-treat patients of $69,54,54,50$, and 41 for TNBC, $\mathrm{HR}^{+} / \mathrm{HER} 2-\mathrm{BC}$, NSCLC, SCLC, and UC, respectively. NR, median OS not reported at this time.

concentrations of $\mathrm{SN}-38 \mathrm{G}$ in the serum might explain this difference, since the re-circulation of SN-38G is suspected to be responsible for late diarrhea in IRI therapy $[117,118]$. A review of the initial data for therapeutic response in patients with CRC, NSCLC, SCLC, and TNBC indicated a trend for improved response rates and clinical benefit in patients given the starting dose of 10 $\mathrm{mg} / \mathrm{kg}$. Thus, with an acceptable safety profile in a diverse population of cancer patients, and with initial evidence of improved responses, $10 \mathrm{mg} / \mathrm{kg}$ was selected as the starting dose for sacituzumab govitecan monotherapy.

The expanded Phase II clinical experience with sacituzumab govitecan in patients given $10 \mathrm{mg} / \mathrm{kg}$ as their starting dose has been reported for TNBC, NSCLC, SCLC, and UC [102-107]. In all these indications, the safety and pharmacokinetics have been similar to that reported for the Phase I and the initial evaluation of the expanded Phase II trials [101, 115]. The majority of these cases express moderate to high levels of TROP-2 in their archived tumor specimens, currently making selection based on TROP-2 expression unnecessary. The initial responserelated results from the phase II trials in TNBC; metastatic hormone-positive, HER2-negative breast cancer; NSCLC; SCLC; and UC are summarized in Table 1.

TNBC is a subgroup ( $15 \%)$ of breast cancer that is not be amenable to hormonal-based therapeutics available for the larger group of breast cancers that express estrogen and/or progesterone, or for those that have elevated human epidermal growth factor-2-(HER2) production [119]. Bardia et al. [106] reported the initial therapy results in 69 patients with metastatic TNBC who had received a median of 5 prior therapies. Twenty-one patients (30\%) achieved a confirmed objective response ( 2 complete responses, 19 partial responses), with the median duration of response at the time being 8.9 months ( $95 \%$ confidence interval (CI), 6.1 to 11.3 months). Based on these data, the FDA awarded sacituzumab govitecan breakthrough therapy designation for this indication. Bardia et al. [107] updated this experience, expanded to 110 patients, all having had $\geq 3$ lines of prior therapy in the metastatic setting. The confirmed on-site objective response rate was maintained, achieving 34\% (3 CR + 34 PR) (Figure 5A), with confirmation by a blinded, independent review of the data achieving a $31 \%$ objective response rate. The duration of response was 7.6 months (95\% CI, 4.8 to 11.3 months), with 12 of the responders still actively receiving treatment at the time of the analysis. Another important observation was that the duration on the last standard therapy was $\geq 6$ months in only $22 / 110(20 \%)$ patients, while sacituzumab govitecan was $\geq 6$ months in $41(37 \%)$ patients. This is very encouraging, since it is usual that response rates decrease with subsequent therapies [120].

Initial recent results in a study of 54 advanced patients with heavily-pretreated hormone-positive, HER2negative, metastatic breast cancer have disclosed an encouraging $31 \%$ objective response rate [135].

Assessable patients $(N=54)$ with metastatic NSCLC who received a median of 3 prior therapies had an objective response rate of $19 \%$ (Figure 5B), a median duration of response of 6 months $(95 \% \mathrm{CI}, 4.8$ to 8.3 months), and a clinical benefit rate of $43 \%$ that included patients with stable disease for $\geq 4$ months [104]. Eighteen of the patients enrolled received prior checkpoint inhibitor therapy, and for those patients, 2 had a partial response $(14 \%)$ and 5 had durable stable disease lasting more than 4 months.

Patients with the more aggressive metastatic SCLC, all of whom failed prior platinum/etoposide therapy, showed promising therapeutic responses to sacituzumab govitecan [103]. In this group that included 50 assessable patients receiving 8 or $10 \mathrm{mg} / \mathrm{kg}, 14 \%$ had a partial response (17\% for those given the $10 \mathrm{mg} / \mathrm{kg}$ dose group) (Figure 5C), with a median duration of response of 5.7 months (95\% CI, 3.6 to 19.9 months). Importantly, 20 patients had stable disease with a median duration of 5.6 months ( $95 \%$ CI, 5.2 to 9.7 months). There was a suggested improvement in PR, clinical benefit rate, and progression-free survival in second-line patients who 
were sensitive to first-line platinum therapy. Further, there was a statistically significant higher overall survival in a subgroup of patients who received prior topotecan therapy vs. no topotecan therapy.

Encouraging results also were reported in patients with previously treated stage IV metastatic UC [102,
105], where $14 / 41$ patients (34\%; including $2 \mathrm{CR}$ ) reported an objective response to sacituzumab govitecan treatment (Figure 5D). Seven of the 14 patients achieving an objective response were continuing treatment at the time of the report, with the duration of response $>6$ months in eleven patients, and a duration $>1$ year in
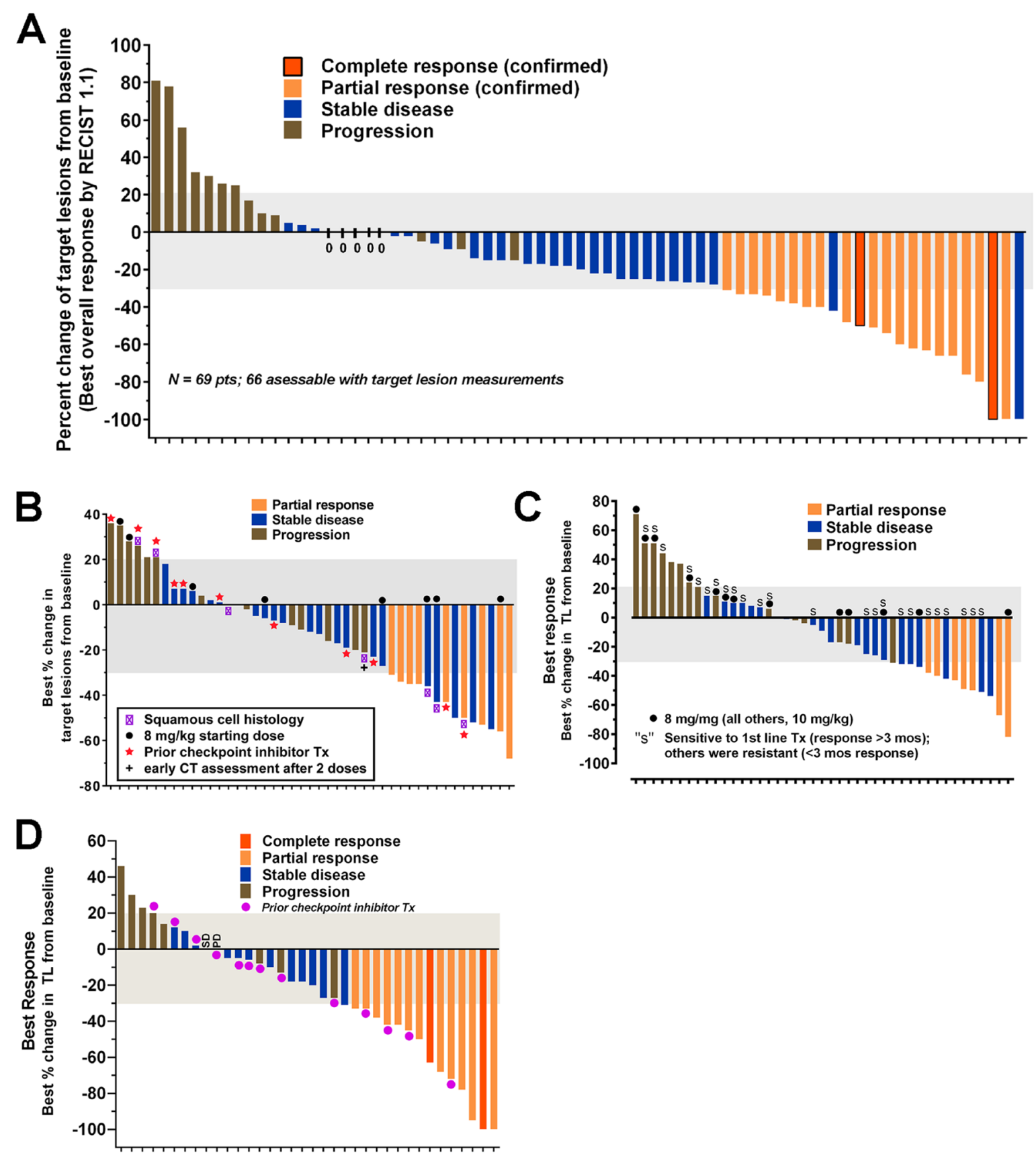

Figure 5: Anti-tumor responses reported in patients with several epithelial cancers who were treated with sacituzumab govitecan, an antibody-drug conjugate targeting TROP-2. Waterfall diagrams depicting the maximum shrinkage observed by investigators in the target lesions selected at baseline after receiving sacituzumab govitecan therapy (response assessment provided only for patients who had at least one follow-up examination). Bar colors provide descriptors for the best overall response achieved in each patient based on RECIST 1.1 criteria. Results are for (A) TNBC as adapted from Bardia et al. [106], (B) NSCLC as adapted from Heist et al. [104] (C), SCLC as adapted from Gray et al. [103], and (D) UC as adapted from Tagawa et al. [105]. Identification of subpopulations of interest for NSCLC (squamous cell) and SCLC (sensitive vs. resistant to first-line platinum therapy) are provided. 
6 patients. Fourteen of the enrolled patients had prior checkpoint inhibitor therapy, and of these, $4(29 \%)$ achieved an objective response. In eleven of these patients, sacituzumab govitecan was given as the fourth or later therapy.

In these trials, neutropenia, fatigue, diarrhea, and anemia were the common adverse events, with grade $\geq 3$ neutropenia being similar to IRI at about $34 \%$. However, grade $\geq 3$ diarrhea was lower ( $\sim 9 \%)$ than typically found with IRI therapy.

Summarizing, this Trop-2 ADC appears to have good activity as a monotherapy in several cancer types expressing TROP-2, and thus represents a paradigmchange in the ADC technology by: (i) using a moderatelytoxic drug, SN-38; (ii) conjugation of the drug to the antibody at a high ratio $(\sim 8: 1)$ without affecting targeting and pharmacokinetics; (iii) use of a pH-sensitive, cleavable linker; (iv) administering repeated, high doses of ADC over prolonged times without provoking an immune response; and $(\mathrm{v})$ reduced and manageable toxicities related only to the drug, such as neutropenia and diarrhea.

\section{PF-06664178; also known as RN927C}

Unlike sacituzumab govitecan, RN927C is an ADC composed of a different humanized anti-TROP-2 antibody conjugated to a more potent auristatin derivative that is a microtubule inhibitor at a maximum substitution of 2.0 [108]. In rats that do not express human TROP-2, the toxicity of the conjugate was primarily hematological, but in monkeys that are cross-reactive with human TROP-2, reversible toxicity was observed in multiple epithelial tissues, including the skin, upper alimentary track, and vagina.

A phase I clinical trial with this ADC was performed in 31 patients with a variety of metastatic epithelial cancers [109]. Nineteen of the patients provided tissue samples for TROP-2 expression, with 13 (68\%) having medium to high expression (i.e., $\geq 50 \%$ of tissue cells having $2+$ to $3+$ staining). Treatment was given once every 21 days, starting at $0.15 \mathrm{mg} / \mathrm{kg}$ and escalating to $4.8 \mathrm{mg} / \mathrm{kg}$, which was considered intolerable, with 3 patients developing a grade 3 rash, one having grade 4 toxic epidermal necrolysis, and another with grade 3 bullous dermatitis. A lower dose level of $2.4 \mathrm{mg} / \mathrm{kg}$ was considered tolerable, but because this dose was considered to lack sufficient therapeutic activity, the trial was stopped before determining the MTD. This ADC was associated with several adverse events, including fatigue, constipation, nausea, chills, infusionrelated reactions, neutropenia, rash, weight decrease, arthralgia, decreased appetite, diarrhea, dyspnea, mucosal inflammation, and pruritus, with neutropenia and rash being the most common $\geq$ grade 3 events. Stable disease was the best response in patients given tolerable doses. Pharmacokinetic analysis revealed the conjugate was stable in serum, but $26 / 30$ patients had post-treatment anti-drug antibody responses.
The safety and efficacy contrast between sacituzumab govitecan and PF-06664178 is quite remarkable and appears to be related to the drug and possibly linkage selection. The highly stable, more potent auristatin-derived ADC appears to have toxicities that are likely associated with TROP-2 targeting, while the less potent and less stable SN-38 conjugate has a safety profile related to its parent drug, IRI, but with an improved therapeutic window [66].

\section{PERSPECTIVES AND CONCLUSIONS}

Although research on TROP-2 dates back almost 40 years [7], there are still many unresolved issues with regard to its role and function in fetal and adult development, as well as in disease, particularly in oncology. Nevertheless, it has already gained an important role in cancer therapy as a predictor of disease activity or prognosis in several cancer types, and indeed appears to have increased expression in a larger number of solid cancers than most other cancer biomarkers. Having extracellular, transmembrane, and intracellular domains implicates TROP-2 in various metabolic pathways, but also permits it to serve as a target for antibody internalization, which is advantageous for delivering cytotoxic agents. Whether TROP-2 expression is critical for antibody targeting and accretion in all neoplasms, how this may be upregulated genetically or epigenetically, and whether it can serve as a target for immunotherapy remain to be studied.

In terms of TROP-2 being a target for immunotherapy, we reported that it is suitable for T-cell therapy using a bispecific antibody that also targets $\mathrm{T}$ cells to the tumor $[121,122]$. This was anticipated by the demonstration that HLA-restricted cytotoxic T lymphocytes killed antigen-presenting cells expressing TROP-2 [123].

A vaccine to treat murine pancreatic cancer was developed by incorporating TROP-2 into an enveloped virus-like particle [124]. This vaccine resulted in a significant reduction in tumor growth associated with activation of tumor-infiltrating $\mathrm{CD} 4^{+}$and $\mathrm{CD}^{+} \mathrm{T}$ cells, as well as natural killer cells, in nonclinical studies. When the vaccine was combined with gemcitabine treatment, survival was increased over the respective monotherapies [124].

Our experience with the unconjugated antibody has not shown antitumor activity in non-clinical tumor models, yet both the antibody and sacituzumab govitecan demonstrate antibody-directed cellular toxicity (ADCC) in vitro [48, 49, 99, 125-127]. However, a human Fab to TROP-2's extracellular domain has been reported to be active in vitro and in vivo against MDA-MB-231 human breast cancer cells [57], thus encouraging further studies with other anti-TROP-2 antibodies having different binding epitopes.

Furthermore, our studies to-date have suggested that selecting patients for therapy based on tumor TROP- 
2 expression is not advantageous, because TROP-2 has a very high (80-90\%) expression in most solid epithelial cancers evaluated. However, we have been unable to detect elevated circulating levels of TROP-2 in the patients studied with sacituzumab govitecan, which requires further study possibly with other test formats. Interestingly, using a recombinant cDNA expression library (SEREX) to analyze the serum of Japanese patients with esophageal squamous cancer, $31 \%$ of 75 patients showed TROP-2 antibodies [67]. This suggests that TROP-2 is immunogenic in certain patients.

The relapse of cancer patients responding to sacituzumab govitecan, even after continuous therapy for over a year, raises the question of resistance forming either to the drug or to the antibody. This needs to be assessed by evaluating tumor biopsies or circulating tumor cells (CTCs) for expression of TROP-2 or response to SN-38 or IRI during the course of therapy, relating these findings to clinical response. CTCs do express TROP-2, even when EpCAM is diminished or absent [128], suggesting that monitoring of TROP-2 in CTC specimens during therapy may be predictive.

Topoisomerase inhibitors, such as SN-38 and IRI, induce multidrug resistance $[129,130]$, so it was of interest to explore the use of an ABCG2 inhibitor to overcome this resistance. Chang et al. showed that human breast and gastric cancer cell lines made resistant to SN38 by continuous exposure to this drug in vitro could have improved survival in vivo when treated with sacituzumab govitecan combined with an ABCG2 inhibitor [131]. Since ABCG2 inhibitors are in clinical development, this may provide another means to improve and prolong efficacy with this ADC.

Tumor resistance also may be overcome or avoided by combining sacituzumab govitecan with other therapeutic agents. The experience with the SN38 (topoisomerase I) ADC, which causes double-strand DNA breaks by inhibiting homologous recombination repair, motivated us to evaluate combinations with PARP1 (poly [ADP-ribose] polymerase 1) inhibitors, also inducing DNA strand breaks. We found synergism without increased host toxicity in several cases [132]. Certainly, expanding the promising results with sacituzumab govitecan as a monotherapy to combinations with agents currently used in various cancer types, especially in earlier therapy settings, deserves to be studied clinically.

Still another intriguing approach is to induce photothermal ablation of cancer by converting nearinfrared laser light to heat. By conjugating hollow gold nanospheres with an anti-TROP-2 antibody that targeted cervical cancer cells (HeLa), the conjugate achieved significant tumor growth-inhibition under laser irradiation. The anti-TROP-2 photothermal therapy was shown to induce apoptosis and DNA damage [133].

Our nonclinical experience measuring TROP2 expression in human tumor xenografts treated with sacituzumab govitecan suggests that there is a general correlation between quantity of TROP-2 and therapeutic response [113]. This is consistent with the clinical experience [66], which suggests that methods to increase tumor expression of TROP-2 could improve therapeutic efficacy and durability of response if relapsing tumors fail to respond because of downregulation of TROP- 2 . Using the analysis of circulating tumor cells for TROP2 expression during therapy, this question could be addressed.

A mesenchymal subset of HNSCC has low TROP2 and high ErbB3 (HER3) expression, yet an improved anti-cancer activity could be achieved with anti-ErbB3 antibodies [30]. In fact, decreased TROP-2 expression has been associated with HNSCC having sarcomatoid (spindle cell) tumors [52]. These authors also reported that combining antibodies against ErbB-3 and TROP-2 results in synergistic therapeutic responses in human HNSCC xenografts [134].

Summarizing, in addition to TROP-2 serving as a prognosticator for a number of cancer types and its role in controlling cell growth and spread by various signaling pathways, its enhanced expression in many human cancers, with minimal expression in normal tissues, makes it an attractive and novel target for precision medicine approaches, as shown with diverse selective antibody conjugates of radionuclides, toxins, and drugs.

Clinically, the first indication for this ADC is expected to be advanced TNBC [106, 107], but encouraging clinical results have also been reported in NSCLC, SCLC, and UC [102-105], as well as more recently in metastatic hormone-positive metastatic breast cancer [135]. Early and preliminary studies also suggest that TROP-2 may be a suitable target for immunotherapy.

Finally, the recognition that a mutation in TROP-2 is related to a rare autosomal-recessive hereditary ocular disease, GDLD, has provoked studies to elucidate the mechanism of action resulting in corneal adhesions, which may also disclose the role and function of TROP-2 more generally in various signaling pathways in health and disease. Indeed, the recent implication of TROP-2 in stem cells involved in myocardial infarction and COPD also raise the interest in this molecule beyond cancer. Thus, despite the exact role of TROP-2 in various normal and diseased states still requiring elucidation, the current body of evidence supports its role as a biomarker and selective target in cancer therapy.

\section{ACKNOWLEDGMENTS}

We appreciate the contributions made by Serengulam V. Govindan, Ph.D., and Thomas M. Cardillo, Ph.D., and the advice of Hans J. Hansen, Ph.D., and Chien-Hsing Chang, Ph.D. We are grateful to the clinical investigators and patients who participated in the clinical trials of sacituzumab govitecan. Finally, we thank 
Benjamin Bonavida, Ph.D., of UCLA, for his helpful review of the manuscript.

\section{CONFLICTS OF INTEREST}

Drs. Goldenberg and Sharkey own Immunomedics stock or stock options, and Dr. Goldenberg holds patented inventions. Dr. Goldenberg is the founder of the Center for Molecular Medicine and Immunology (CMMI), and also the retired founder of Immunomedics, Inc., and IBC Pharmaceuticals, Inc.

\section{FUNDING}

The authors' studies were supported in part by an Outstanding Investigator Grant to D.M.G. from the National Cancer Institute (CA39841), NIH grant S07RR05903, American Cancer Society Grant EDT-16, Essex Norwest Health and Breath Association, NJ Commission on Cancer Research, Claire Sullivan Memorial Fund at the Garden State Cancer Center, Garden State Cancer Center Foundation, Escalon Foundation, Immunomedics, Inc., and IBC Pharmaceuticals, Inc.

\section{REFERENCES}

1. Jackson SE, Chester JD. Personalised cancer medicine. Int J Cancer. 2015; 137:262-266.

2. Griffin J. The biology of signal transduction inhibition: basic science to novel therapies. Semin Oncol. 2001; 28:3-8.

3. Soverini S, Mancini M, Bavaro L, Cavo M, Martinelli G. Chronic myeloid leukemia: the paradigm of targeting oncogenic tyrosine kinase signaling and counteracting resistance for successful cancer therapy. Mol Cancer. 2018; 17:49.

4. Virji MA, Mercer DW, Herberman RB. Tumor markers in cancer diagnosis and prognosis. CA Cancer J Clin. 1988; 38:104-126.

5. Sharkey RM, Goldenberg DM. Targeted therapy of cancer: new prospects for antibodies and immunoconjugates. CA Cancer J Clin. 2006; 56:226-243.

6. Sgouros G, Goldenberg DM. Radiopharmaceutical therapy in the era of precision medicine. Eur J Cancer. 2014; 50:2360-2363.

7. Lipinski M, Parks DR, Rouse RV, Herzenberg LA. Human trophoblast cell-surface antigens defined by monoclonal antibodies. Proc Natl Acad Sci U S A. 1981; 78:5147-5150.

8. Cubas R, Li M, Chen C, Yao Q. Trop2: a possible therapeutic target for late stage epithelial carcinomas. Biochim Biophys Acta. 2009; 1796:309-314.

9. Shvartsur A, Bonavida B. Trop2 and its overexpression in cancers: regulation and clinical/therapeutic implications.
Genes Cancer. 2015; 6:84-105. https://doi.org/10.18632/ genesandcancer.40.

10. Stein R, Chen S, Sharkey RM, Goldenberg DM. Murine monoclonal antibodies raised against human non-small cell carcinoma of the lung: specificity and tumor targeting. Cancer Res. 1990; 50:1330-1336.

11. Stein R, Basu A, Chen S, Shih LB, Goldenberg DM. Specificity and properties of MAb RS7-3G11 and the antigen defined by this pancarcinoma monoclonal antibody. Int J Cancer. 1993; 55:938-946.

12. De Leij L, Helrich W, Stein R, Mattes MJ. SCLC-cluster-2 antibodies detect the pancarcinoma/epithelial glycoprotein EGP-2. Int J Cancer Suppl. 1994; 8:60-63.

13. Stein R, Basu A, Goldenberg DM, Lloyd KO, Mattes MJ. Characterization of cluster 13: the epithelial/carcinoma antigen recognized by MAb RS7. Int J Cancer Suppl. 1994; 8:98-102.

14. Basu A, Goldenberg DM, Stein R. The epithelial/carcinoma antigen EGP-1, recognized by monoclonal antibody RS7-3G11, is phosphorylated on serine 303. Int J Cancer. $1995 ; 62: 472-479$.

15. Shih LB, Xuan H, Aninipot R, Stein R, Goldenberg DM. In vitro and in vivo reactivity of an internalizing antibody, RS7, with human breast cancer. Cancer Res. 1995 (Suppl 23); 55:5857s-5863s

16. Fornaro M, Dell'Arciprete R, Stella M, Bucci C, Nutini M, Capri MG, Alberti S. Cloning of the gene encoding Trop-2, a cell-surface glycoprotein expressed by human carcinomas. Int J Cancer. 1995; 62:610-618.

17. Miotti S, Canevari S, Menard S, Mezzanzanica D, Porro G, Pupa SM, Regazzoni M, Tagliabue E, Colnaghi MI. Characterization of human ovarian carcinoma-associated antigens defined by novel monoclonal antibodies with tumor-restricted specificity. Int J Cancer. 1987; 39:297-303.

18. Calabrese G, Crescenzi C, Morizio E, Palka G, Guerra E, Alberti S. Assignment of TACSTD1 (alias TROP1, M4S1) to human chromosome $2 \mathrm{p} 21$ and refinement of mapping of TACSTD2 (alias TROP2, M1S1) to human chromosome 1 p32 by in situ hybridization. Cytogenet Cell Genet. 2001; 92:164-165.

19. Linnenbach AJ, Seng BA, Wu S, Robbins S, Scollon M, Pyrc JJ, Druck T, Huebner K. Retroposition in a family of carcinoma-associated antigen genes. Mol Cell Biol. 1993; 13:1507-1515.

20. McDougall AR, Tolcos M, Hooper SB, Cole TJ, Wallace MJ. Trop2: from development to disease. Dev Dyn. 2015; 244:99-109.

21. Sozo F, Wallace MJ, Zahra VA, Filby CE, Hooper SB. Gene expression profiling during increased fetal lung expansion identifies genes likely to regulate development of the distal airways. Physiol Genomics. 2006; 24:105-113.

22. Linnenbach AJ, Wojcierowski J, Wu SA, Pyrc JJ, Ross AH, Dietzschold B, Speicher D, Koprowski H. Sequence investigation of the major gastrointestinal tumor-associated 
antigen gene family, GA733. Proc Natl Acad Sci U S A. 1989; 86:27-31.

23. Ripani E, Sacchetti A, Corda D, Alberti S. Human Trop-2 is a tumor-associated calcium signal transducer. Int J Cancer. 1998; 76:671-676.

24. Alberti S. HIKE, a candidate protein binding site for $\mathrm{PH}$ domains, is a major regulatory region of Gbeta proteins. Proteins. 1999; 35:360-363.

25. Alberti S. A phosphoinositide-binding sequence is shared by $\mathrm{PH}$ domain target molecules - a model for the binding of PH domains to proteins. Proteins. 1998; 31:1-9.

26. Ciccarelli FD, Acciarito A, Alberti S. Large and diverse numbers of human diseases with HIKE mutations. Hum Mol Genet. 2000; 9:1001-1007.

27. El Sewedy T, Fornaro M, Alberti S. Cloning of the murine TROP2 gene: conservation of a PIP2-binding sequence in the cytoplasmic domain of TROP-2. Int J Cancer. 1998; 75:324-330.

28. Novinec M, Kordis D, Turk V, Lenarcic B. Diversity and evolution of the thyroglobulin type-1 domain superfamily. Mol Biol Evol. 2006; 23:744-755.

29. Lin JC, Wu YY, Wu JY, Lin TC, Wu CT, Chang YL, Jou YS, Hong TM, Yang PC. TROP2 is epigenetically inactivated and modulates IGF-1R signalling in lung adenocarcinoma. EMBO Mol Med. 2012; 4:472-485.

30. Zhang K, Jones L, Lim S, Maher CA, Adkins D, Lewis J, Kimple RJ, Fertig EJ, Chung CH, Van Tine BA, Ellis MJ, Herrlich A, Michel LS. Loss of Trop2 causes ErbB3 activation through a neuregulin-1-dependent mechanism in the mesenchymal subtype of HNSCC. Oncotarget. 2014; 5:9281-9294. https://doi.org/10.18632/oncotarget.2423.

31. Cubas R, Zhang S, Li M, Chen C, Yao Q. Trop2 expression contributes to tumor pathogenesis by activating the ERK MAPK pathway. Mol Cancer. 2010; 9:253.

32. Szala S, Froehlich M, Scollon M, Kasai Y, Steplewski Z, Koprowski H, Linnenbach AJ. Molecular cloning of cDNA for the carcinoma-associated antigen GA733-2. Proc Natl Acad Sci U S A. 1990; 87:3542-3546.

33. Balzar M, Winter MJ, de Boer CJ, Litvinov SV. The biology of the 17-1A antigen (Ep-CAM). J Mol Med (Berl). 1999; 77:699-712.

34. Schnell U, Cirulli V, Giepmans BN. EpCAM: structure and function in health and disease. Biochim Biophys Acta. 2013; 1828:1989-2001.

35. Villablanca EJ, Renucci A, Sapede D, Lec V, Soubiran F, Sandoval PC, Dambly-Chaudiere C, Ghysen A, Allende ML. Control of cell migration in the zebrafish lateral line: implication of the gene "tumour-associated calcium signal transducer,” tacstd. Dev Dyn. 2006; 235:1578-1588.

36. Vidmar T, Pavsic M, Lenarcic B. Biochemical and preliminary X-ray characterization of the tumor-associated calcium signal transducer 2 (Trop2) ectodomain. Protein Expr Purif. 2013; 91:69-76.
37. Xu P, Zhao Y, Liu K, Lin S, Liu X, Wang M, Yang P, Tian T, Zhu YY, Dai Z. Prognostic role and clinical significance of trophoblast cell surface antigen 2 in various carcinomas. Cancer Manag Res. 2017; 9:821-837.

38. Zeng P, Chen MB, Zhou LN, Tang M, Liu CY, Lu PH. Impact of TROP2 expression on prognosis in solid tumors: A systematic review and meta-analysis. Sci Rep. 2016; 6:33658.

39. Jiang A, Gao X, Zhang D, Zhang L, Lu H. Expression and clinical significance of the Trop-2 gene in advanced nonsmall cell lung carcinoma. Oncol Lett. 2013; 6:375-380.

40. Zhao P, Yu HZ, Cai JH. Clinical investigation of TROP-2 as an independent biomarker and potential therapeutic target in colon cancer. Mol Med Rep. 2015; 12:4364-4369.

41. Guerra E, Trerotola M, Aloisi AL, Tripaldi R, Vacca G, La Sorda R, Lattanzio R, Piantelli M, Alberti S. The Trop-2 signalling network in cancer growth. Oncogene. 2013; 32:1594-1600.

42. Lin H, Huang JF, Qiu JR, Zhang HL, Tang XJ, Li H, Wang CJ, Wang ZC, Feng ZQ, Zhu J. Significantly upregulated TACSTD2 and cyclin D1 correlate with poor prognosis of invasive ductal breast cancer. Exp Mol Pathol. 2013; 94:73-78.

43. Liu T, Liu Y, Bao X, Tian J, Liu Y, Yang X. Overexpression of TROP2 predicts poor prognosis of patients with cervical cancer and promotes the proliferation and invasion of cervical cancer cells by regulating ERK signaling pathway. PLoS One. 2013; 8:e75864.

44. Mojica WD, Brandwein-Weber M, Korangy EA. A case of metastatic lobular carcinoma with overexpression of Trop2: Implications for the consideration of novel therapeutics. Breast J. 2017; 23:757-759.

45. Santin AD, Zhan F, Bellone S, Palmieri M, Cane S, Bignotti E, Anfossi S, Gokden M, Dunn D, Roman JJ, O’Brien TJ, Tian E, Cannon MJ, et al. Gene expression profiles in primary ovarian serous papillary tumors and normal ovarian epithelium: identification of candidate molecular markers for ovarian cancer diagnosis and therapy. Int $\mathrm{J}$ Cancer. 2004; 112:14-25.

46. Simms A, Jacob RP, Cohen C, Siddiqui MT. TROP-2 expression in papillary thyroid carcinoma: Potential diagnostic utility. Diagn Cytopathol. 2016; 44:26-31.

47. Trerotola M, Ganguly KK, Fazli L, Fedele C, Lu H, Dutta A, Liu Q, De Angelis T, Riddell LW, Riobo NA, Gleave ME, Zoubeidi A, Pestell RG, et al. Trop-2 is up-regulated in invasive prostate cancer and displaces FAK from focal contacts. Oncotarget. 2015; 6:14318-14328. https://doi. org/10.18632/oncotarget.3960 Erratum in: Erratum: Trop-2 is up-regulated in invasive prostate cancer and displaces FAK from focal contacts. [Oncotarget. 2015].

48. Varughese J, Cocco E, Bellone S, Bellone M, Todeschini P, Carrara L, Schwartz PE, Rutherford TJ, Pecorelli S, Santin AD. High-grade, chemotherapy-resistant primary ovarian carcinoma cell lines overexpress human trophoblast 
cell-surface marker (Trop-2) and are highly sensitive to immunotherapy with hRS7, a humanized monoclonal antiTrop-2 antibody. Gynecol Oncol. 2011; 122:171-177.

49. Varughese J, Cocco E, Bellone S, Ratner E, Silasi DA, Azodi M, Schwartz PE, Rutherford TJ, Buza N, Pecorelli $\mathrm{S}$, Santin AD. Cervical carcinomas overexpress human trophoblast cell-surface marker (Trop-2) and are highly sensitive to immunotherapy with hRS7, a humanized monoclonal anti-Trop-2 antibody. Am J Obstet Gynecol. 2011; 205:567.

50. Ambrogi F, Fornili M, Boracchi P, Trerotola M, Relli V, Simeone P, La Sorda R, Lattanzio R, Querzoli P, Pedriali M, Piantelli M, Biganzoli E, Alberti S. Trop-2 is a determinant of breast cancer survival. PLoS One. 2014; 9:e96993.

51. Wang J, Day R, Dong Y, Weintraub SJ, Michel L. Identification of Trop-2 as an oncogene and an attractive therapeutic target in colon cancers. Mol Cancer Ther. 2008; 7:280-285.

52. Wang J, Zhang K, Grabowska D, Li A, Dong Y, Day R, Humphrey P, Lewis J, Kladney RD, Arbeit JM, Weber JD, Chung $\mathrm{CH}$, Michel LS. Loss of Trop2 promotes carcinogenesis and features of epithelial to mesenchymal transition in squamous cell carcinoma. Mol Cancer Res. 2011; 9:1686-1695.

53. Trerotola M, Cantanelli P, Guerra E, Tripaldi R, Aloisi AL, Bonasera V, Lattanzio R, de Lange R, Weidle UH, Piantelli M, Alberti S. Upregulation of Trop-2 quantitatively stimulates human cancer growth. Oncogene. 2013; 32:222-233.

54. Gao XY, Zhu YH, Zhang LX, Lu HY, Jiang AG. siRNA targeting of Trop2 suppresses the proliferation and invasion of lung adenocarcinoma H460 cells. Exp Ther Med. 2015; 10:429-434.

55. Wu B, Yu C, Zhou B, Huang T, Gao L, Liu T, Yang X. Overexpression of TROP2 promotes proliferation and invasion of ovarian cancer cells. Exp Ther Med. 2017; 14:1947-1952.

56. Li X, Teng S, Zhang Y, Zhang W, Zhang X, Xu K, Yao $\mathrm{H}$, Yao J, Wang H, Liang X, Hu Z. TROP2 promotes proliferation, migration and metastasis of gallbladder cancer cells by regulating PI3K/AKT pathway and inducing EMT. Oncotarget. 2017; 8:47052-47063. https://doi.org/10.18632/ oncotarget. 16789.

57. Lin H, Zhang H, Wang J, Lu M, Zheng F, Wang C, Tang X, Xu N, Chen R, Zhang D, Zhao P, Zhu J, Mao Y, et al. A novel human Fab antibody for Trop2 inhibits breast cancer growth in vitro and in vivo. Int J Cancer. 2014; 134:1239-1249.

58. Stepan LP, Trueblood ES, Hale K, Babcook J, Borges L, Sutherland CL. Expression of Trop2 cell surface glycoprotein in normal and tumor tissues: potential implications as a cancer therapeutic target. J Histochem Cytochem. 2011; 59:701-710.
59. Zhao W, Ding G, Wen J, Tang Q, Yong H, Zhu H, Zhang S, Qiu Z, Feng Z, Zhu J. Correlation between Trop2 and amphiregulin coexpression and overall survival in gastric cancer. Cancer Med. 2017; 6:994-1001.

60. Nakanishi H, Taccioli C, Palatini J, Fernandez-Cymering C, Cui R, Kim T, Volinia S, Croce CM. Loss of miR-125b-1 contributes to head and neck cancer development by dysregulating TACSTD2 and MAPK pathway. Oncogene. 2014; 33:702-712.

61. Zhao P, Zhang Z. TNF-alpha promotes colon cancer cell migration and invasion by upregulating TROP-2. Oncol Lett. 2018; 15:3820-3827.

62. Bobos M, Kotoula V, Kaloutsi V, Karayannopoulou G, Papadimitriou CS, Kostopoulos I. Aberrant CCND1 copies and cyclin D1 mRNA expression do not result in the production of functional cyclin D1 protein in anaplastic large cell lymphoma. Histol Histopathol. 2009; 24:1035-1048.

63. Huang H, Groth J, Sossey-Alaoui K, Hawthorn L, Beall $\mathrm{S}$, Geradts J. Aberrant expression of novel and previously described cell membrane markers in human breast cancer cell lines and tumors. Clin Cancer Res. 2005; 11:4357-4364.

64. Kobayashi H, Minami Y, Anami Y, Kondou Y, Iijima T, Kano J, Morishita Y, Tsuta K, Hayashi S, Noguchi M. Expression of the GA733 gene family and its relationship to prognosis in pulmonary adenocarcinoma. Virchows Arch. 2010; 457:69-76.

65. Guerra E, Trerotola M, Dell AR, Bonasera V, Palombo B, El-Sewedy T, Ciccimarra T, Crescenzi C, Lorenzini F, Rossi C, Vacca G, Lattanzio R, Piantelli M, et al. A bicistronic CYCLIN D1-TROP2 mRNA chimera demonstrates a novel oncogenic mechanism in human cancer. Cancer Res. 2008; 68:8113-8121.

66. Goldenberg DM, Cardillo TM, Govindan SV, Rossi EA, Sharkey RM. Trop-2 is a novel target for solid cancer therapy with sacituzumab govitecan (IMMU-132), an antibody-drug conjugate (ADC). Oncotarget. 2015; 6:22496-22512. https://doi.org/10.18632/oncotarget.4318.

67. Nakashima K, Shimada H, Ochiai T, Kuboshima M, Kuroiwa N, Okazumi S, Matsubara H, Nomura F, Takiguchi M, Hiwasa T. Serological identification of TROP2 by recombinant cDNA expression cloning using sera of patients with esophageal squamous cell carcinoma. Int $\mathbf{J}$ Cancer. 2004; 112:1029-1035.

68. Goldstein AS, Lawson DA, Cheng D, Sun W, Garraway IP, Witte ON. Trop2 identifies a subpopulation of murine and human prostate basal cells with stem cell characteristics. Proc Natl Acad Sci U S A. 2008; 105:20882-20887.

69. Goldstein AS, Huang J, Guo C, Garraway IP, Witte ON. Identification of a cell of origin for human prostate cancer. Science. 2010; 329:568-571.

70. Okabe M, Tsukahara Y, Tanaka M, Suzuki K, Saito S, Kamiya Y, Tsujimura T, Nakamura K, Miyajima A. Potential 
hepatic stem cells reside in EpCAM+ cells of normal and injured mouse liver. Development. 2009; 136:1951-1960.

71. Memarzadeh S, Zong Y, Janzen DM, Goldstein AS, Cheng D, Kurita T, Schafenacker AM, Huang J, Witte ON. Cellautonomous activation of the PI3-kinase pathway initiates endometrial cancer from adult uterine epithelium. Proc Natl Acad Sci U S A. 2010; 107:17298-17303.

72. Park JW, Lee JK, Phillips JW, Huang P, Cheng D, Huang J, Witte ON. Prostate epithelial cell of origin determines cancer differentiation state in an organoid transformation assay. Proc Natl Acad Sci U S A. 2016; 113:4482-4487.

73. Stoyanova T, Cooper AR, Drake JM, Liu X, Armstrong AJ, Pienta KJ, Zhang H, Kohn DB, Huang J, Witte ON, Goldstein AS. Prostate cancer originating in basal cells progresses to adenocarcinoma propagated by luminal-like cells. Proc Natl Acad Sci U S A. 2013; 110:20111-20116.

74. Trerotola M, Li J, Alberti S, Languino LR. Trop-2 inhibits prostate cancer cell adhesion to fibronectin through the beta1 integrin-RACK1 axis. J Cell Physiol. 2012; 227:3670-3677.

75. Trerotola M, Jernigan DL, Liu Q, Siddiqui J, Fatatis A, Languino LR. Trop-2 promotes prostate cancer metastasis by modulating beta(1) integrin functions. Cancer Res. 2013; 73:3155-3167.

76. Yang J, Zhou Y, Liu B, Wang H, Du X. Trop2 plays a cardioprotective role by promoting cardiac c-kit+ cell proliferation and inhibition of apoptosis in the acute phase of myocardial infarction. Int J Mol Med. 2013; 31:1298-1304.

77. Liu Q, Li H, Wang Q, Zhang Y, Wang W, Dou S, Xiao W. Increased expression of TROP2 in airway basal cells potentially contributes to airway remodeling in chronic obstructive pulmonary disease. Respir Res. 2016; 17:159.

78. Tsujikawa M, Kurahashi H, Tanaka T, Nishida $K$, Shimomura Y, Tano Y, Nakamura Y. Identification of the gene responsible for gelatinous drop-like corneal dystrophy. Nat Genet. 1999; 21:420-423.

79. Nakaizumi G. A rare case of corneal dystrophy. Acta Soc Ophthalmol Jpn. 1914; 18:949-950.

80. Jongkhajornpong P, Lekhanont K, Ueta M, Kitazawa K, Kawasaki S, Kinoshita S. Novel TACSTD2 mutation in gelatinous drop-like corneal dystrophy. Hum Genome Var. 2015; 2:15047.

81. Takaoka M, Nakamura T, Ban Y, Kinoshita S. Phenotypic investigation of cell junction-related proteins in gelatinous drop-like corneal dystrophy. Invest Ophthalmol Vis Sci. 2007; 48:1095-1101.

82. Nakatsukasa M, Kawasaki S, Yamasaki K, Fukuoka H, Matsuda A, Tsujikawa M, Tanioka H, Nagata-Takaoka M, Hamuro J, Kinoshita S. Tumor-associated calcium signal transducer 2 is required for the proper subcellular localization of claudin 1 and 7: implications in the pathogenesis of gelatinous drop-like corneal dystrophy. Am J Pathol. 2010; 177:1344-1355.
83. Stein R, Blumenthal R, Sharkey RM, Goldenberg DM. Comparative biodistribution and radioimmunotherapy of monoclonal antibody RS7 and its $\mathrm{F}(\mathrm{ab}$ ') 2 in nude mice bearing human tumor xenografts. Cancer. 1994; 73:816-823.

84. van Rij CM, Sharkey RM, Goldenberg DM, Frielink C, Molkenboer JD, Franssen GM, van Weerden WM, Oyen WJ, Boerman OC. Imaging of prostate cancer with immunoPET and immuno-SPECT using a radiolabeled anti-EGP-1 monoclonal antibody. J Nucl Med. 2011; 52:1601-1607.

85. Stein R, Chen S, Haim S, Goldenberg DM. Advantage of yttrium-90-labeled over iodine-131-labeled monoclonal antibodies in the treatment of a human lung carcinoma xenograft. Cancer. 1997; 80:2636-2641.

86. Stein R, Goldenberg DM, Thorpe SR, Mattes MJ. Advantage of a residualizing iodine radiolabel for radioimmunotherapy of xenografts of human non-small-cell carcinoma of the lung. J Nucl Med. 1997; 38:391-395.

87. Govindan SV, Mattes MJ, Stein R, McBride BJ, Karacay H, Goldenberg DM, Hansen HJ, Griffiths GL. Labeling of monoclonal antibodies with diethylenetriaminepentaacetic acid-appended radioiodinated peptides containing D-amino acids. Bioconjug Chem. 1999; 10:231-240.

88. Stein R, Govindan SV, Chen S, Reed L, Richel H, Griffiths GL, Hansen HJ, Goldenberg DM. Radioimmunotherapy of a human lung cancer xenograft with monoclonal antibody RS7: evaluation of ${ }^{177} \mathrm{Lu}$ and comparison of its efficacy with that of ${ }^{90} \mathrm{Y}$ and residualizing ${ }^{131} \mathrm{I}$. J Nucl Med. 2001; 42:967-974.

89. Stein R, Govindan SV, Chen S, Reed L, Spiegelman H, Griffiths GL, Hansen HJ, Goldenberg DM. Successful therapy of a human lung cancer xenograft using MAb RS7 labeled with residualizing radioiodine. Crit Rev Oncol Hematol. 2001; 39:173-180.

90. Sharkey RM, van Rij CM, Karacay H, Rossi EA, Frielink C, Regino C, Cardillo TM, McBride WJ, Chang CH, Boerman OC, Goldenberg DM. A new Tri-Fab bispecific antibody for pretargeting Trop-2-expressing epithelial cancers. J Nucl Med. 2012; 53:1625-1632.

91. van Rij CM, Lutje S, Frielink C, Sharkey RM, Goldenberg DM, Franssen GM, McBride WJ, Rossi EA, Oyen WJ, Boerman OC. Pretargeted immuno-PET and radioimmunotherapy of prostate cancer with an antiTROP-2 x anti-HSG bispecific antibody. Eur J Nucl Med Mol Imaging. 2013; 40:1377-1383.

92. van Rij CM, Frielink C, Goldenberg DM, Sharkey RM, Lutje S, McBride WJ, Oyen WJ, Boerman OC. Pretargeted radioimmunotherapy of prostate cancer with an antiTROP-2 $\mathrm{x}$ anti-HSG bispecific antibody and a ${ }^{177} \mathrm{Lu}$-labeled peptide. Cancer Biother Radiopharm. 2014; 29:323-329.

93. van Rij CM, Frielink C, Goldenberg DM, Sharkey RM, Franssen GM, Lutje S, McBride WJ, Oyen WJ, Boerman OC. Pretargeted immunoPET of prostate cancer with an anti-TROP-2 $\mathrm{x}$ anti-HSG bispecific antibody in mice with PC3 xenografts. Mol Imaging Biol. 2015; 17:94-101. 
94. Chang CH, Gupta P, Michel R, Loo M, Wang Y, Cardillo TM, Goldenberg DM. Ranpirnase (frog RNase) targeted with a humanized, internalizing, anti-Trop-2 antibody has potent cytotoxicity against diverse epithelial cancer cells. Mol Cancer Ther. 2010; 9:2276-2286.

95. Liu D, Cardillo TM, Wang Y, Rossi EA, Goldenberg DM, Chang $\mathrm{CH}$. Trop-2-targeting tetrakis-ranpirnase has potent antitumor activity against triple-negative breast cancer. Mol Cancer. 2014; 13:53.

96. Rossi EA, Goldenberg DM, Cardillo TM, McBride WJ, Sharkey RM, Chang CH. Stably tethered multifunctional structures of defined composition made by the dock and lock method for use in cancer targeting. Proc Natl Acad Sci U S A. 2006; 103:6841-6846.

97. Chang CH, Rossi EA, Goldenberg DM. The dock and lock method: a novel platform technology for building multivalent, multifunctional structures of defined composition with retained bioactivity. Clin Cancer Res. 2007; 13:5586s-5591s.

98. Rossi EA, Goldenberg DM, Chang CH. The dock-andlock method combines recombinant engineering with sitespecific covalent conjugation to generate multifunctional structures. Bioconjug Chem. 2012; 23:309-323.

99. Cardillo TM, Govindan SV, Sharkey RM, Trisal P, Goldenberg DM. Humanized anti-Trop-2 IgG-SN-38 conjugate for effective treatment of diverse epithelial cancers: preclinical studies in human cancer xenograft models and monkeys. Clin Cancer Res. 2011; 17:3157-3169.

100. Cardillo TM, Govindan SV, Sharkey RM, Trisal P, Arrojo R, Liu D, Rossi EA, Chang CH, Goldenberg DM. Sacituzumab govitecan (IMMU-132), an anti-Trop-2/SN-38 antibody-drug conjugate: Characterization and efficacy in pancreatic, gastric, and other cancers. Bioconjug Chem. 2015; 26:919-931.

101. Starodub AN, Ocean AJ, Shah MA, Guarino MJ, Picozzi VJ Jr, Vahdat LT, Thomas SS, Govindan SV, Maliakal PP, Wegener WA, Hamburger SA, Sharkey RM, Goldenberg DM. First-inhuman trial of a novel anti-Trop-2 antibody-SN-38 conjugate, sacituzumab govitecan, for the treatment of diverse metastatic solid tumors. Clin Cancer Res. 2015; 21:3870-3878.

102. Faltas B, Goldenberg DM, Ocean AJ, Govindan SV, Wilhelm F, Sharkey RM, Hajdenberg J, Hodes G, Nanus DM, Tagawa ST. Sacituzumab govitecan, a novel antibody-drug conjugate, in patients with metastatic platinum-resistant urothelial carcinoma. Clin Genitourin Cancer. 2016; 14:e75-79.

103. Gray JE, Heist RS, Starodub AN, Camidge DR, Kio EA, Masters GA, Purcell WT, Guarino MJ, Misleh J, Schneider CJ, Schneider BJ, Ocean A, Johnson T, et al. Therapy of small cell lung cancer (SCLC) with a topoisomeraseI-inhibiting antibody-drug conjugate (ADC) targeting Trop-2, sacituzumab govitecan. Clin Cancer Res. 2017; 23:5711-5719.

104. Heist RS, Guarino MJ, Masters G, Purcell WT, Starodub AN, Horn L, Scheff RJ, Bardia A, Messersmith WA, Berlin J, Ocean AJ, Govindan SV, Maliakal P, et al. Therapy of advanced non-small-cell lung cancer with an SN-38-antiTrop-2 drug conjugate, sacituzumab govitecan. J Clin Oncol. 2017; 35:2790-2797.

105. Tagawa ST, Faltas B, Lam E, Saylor P, Bardia A, Hajdenberg J, Morgans AK, Lim E, Kalinsky K, Petrylak DP, Galsky MD, Maliakal P, Mudenda B, et al. Sacituzumab govitecan (IMMU-132) for patients with pretreated metastatic urothelial cancers (UC): Interim results. Ann Oncol. 2017; 28:301.

106. Bardia A, Mayer IA, Diamond JR, Moroose RL, Isakoff SJ, Starodub AN, Shah NC, O’Shaughnessy J, Kalinsky K, Guarino M, Abramson V, Juric D, Tolaney SM, et al. Efficacy and safety of anti-Trop-2 antibody drug conjugate sacituzumab govitecan (IMMU-132) in heavily pretreated patients with metastatic triple-negative breast cancer. J Clin Oncol. 2017; 35:2141-2148.

107. Bardia A, Vahdat LT, Diamond JR, Kalinsky K, O'Shaughnessy J, Moroose RL, Isakoff SJ, Tolaney SM, Santin AD, Abramson V, Shah NC, Govindan SV, Maliakal P, et al. Sacituzumab govitecan (IMMU-132), an anti-Trop2-SN-38 antibody-drug conjugate, as $\geq 3$ rd-line therapeutic option for patients with relapsed/refractory metastatic triplenegative breast cancer (mTNBC): Efficacy results. San Antonio Breast Cancer Symposium. 2017; GS1-07.

108. Strop P, Tran TT, Dorywalska M, Delaria K, Dushin R, Wong OK, Ho WH, Zhou D, Wu A, Kraynov E, Aschenbrenner L, Han B, O'Donnell CJ, et al. RN927C, a site-specific Trop-2 antibody-drug conjugate (ADC) with enhanced stability, is highly efficacious in preclinical solid tumor models. Mol Cancer Ther. 2016; 15:2698-2708.

109. King GT, Eaton KD, Beagle BR, Zopf CJ, Wong GY, Krupka HI, Hua SY, Messersmith WA, El-Khoueiry AB. A phase 1, dose-escalation study of PF-06664178, an antiTrop-2/Aur0101 antibody-drug conjugate in patients with advanced or metastatic solid tumors. Invest New Drugs. 2018 Jan 15. https://doi.org/10.1007/s10637-018-0560-6. [Epub ahead of print].

110. Son S, Shin S, Rao NV, Um W, Jeon J, Ko H, Deepagan VG, Kwon S, Lee JY, Park JH. Anti-Trop2 antibody-conjugated bioreducible nanoparticles for targeted triple negative breast cancer therapy. Int J Biol Macromol. 2017; 110:406-415.

111. Mao Y, Wang X, Zheng F, Wang C, Tang Q, Tang X, Xu N, Zhang H, Zhang D, Xiong L, Liang J, Zhu J. The tumorinhibitory effectiveness of a novel anti-Trop2 Fab conjugate in pancreatic cancer. Oncotarget. 2016; 7:24810-24823. https://doi.org/10.18632/oncotarget.8529.

112. Moon SJ, Govindan SV, Cardillo TM, D'Souza CA, Hansen HJ, Goldenberg DM. Antibody conjugates of 7-ethyl10-hydroxycamptothecin (SN-38) for targeted cancer chemotherapy. J Med Chem. 2008; 51:6916-6926.

113. Cardillo TM, Mostafa AA, Rossi DL, Liu D, Chang CH, Sharkey RM, Goldenberg DM. Treatment of high Trop2-expressing triple-negative breast cancer (TNBC) with sacituzumab govitecan (IMMU-132) overcomes homologous 
recombination repair (HRR) rescue mediated by Rad51. Cancer Res. 2017; 77:3193. https://doi.org/10.1158/15387445.AM2017-3193.

114. Sharkey RM, McBride WJ, Cardillo TM, Govindan SV, Wang Y, Rossi EA, Chang CH, Goldenberg DM. Enhanced delivery of SN-38 to human tumor xenografts with an antiTrop-2-SN-38 antibody conjugate (sacituzumab govitecan). Clin Cancer Res. 2015; 21:5131-5138.

115. Ocean AJ, Starodub AN, Bardia A, Vahdat LT, Isakoff SJ, Guarino M, Messersmith WA, Picozzi VJ, Mayer IA, Wegener WA, Maliakal P, Govindan SV, Sharkey RM, et al. Sacituzumab govitecan (IMMU-132), an anti-Trop-2-SN-38 antibody-drug conjugate for the treatment of diverse epithelial cancers: Safety and pharmacokinetics. Cancer. 2017; 123:3843-3854.

116. Xie R, Mathijssen RH, Sparreboom A, Verweij J, Karlsson MO. Clinical pharmacokinetics of irinotecan and its metabolites: a population analysis. J Clin Oncol. 2002; 20:3293-3301.

117. Xie R, Mathijssen RH, Sparreboom A, Verweij J, Karlsson MO. Clinical pharmacokinetics of irinotecan and its metabolites in relation with diarrhea. Clin Pharmacol Ther. 2002; 72:265-275.

118. Stein A, Voigt W, Jordan K. Chemotherapy-induced diarrhea: pathophysiology, frequency and guideline-based management. Ther Adv Med Oncol. 2010; 2:51-63.

119. Anders CK, Abramson V, Tan T, Dent R. The evolution of triple-negative breast cancer: From biology to novel therapeutics. Am Soc Clin Oncol Educ Book. 2016; 35:34- 42.

120. Dufresne A, Pivot X, Tournigand C, Facchini T, Altweegg T, Chaigneau L, De Gramont A. Impact of chemotherapy beyond the first line in patients with metastatic breast cancer. Breast Cancer Res Treat. 2008; 107:275-279.

121. Rossi DL, Rossi EA, Cardillo TM, Goldenberg DM, Chang $\mathrm{CH}$. A new class of bispecific antibodies to redirect T cells for cancer immunotherapy. MAbs. 2014; 6:381-391.

122. Chang $\mathrm{CH}$, Goldenberg DM. Enhancing the antitumor potency of $\mathrm{T}$ cells redirected by bispecific antibodies. Oncoscience. 2017; 4:120-121. https://doi.org/10.18632/ oncoscience. 366 .

123. Mangino G, Grazia Capri M, Barnaba V, Alberti S. Presentation of native TROP-2 tumor antigens to human cytotoxic $\mathrm{T}$ lymphocytes by engineered antigen-presenting cells. Int J Cancer. 2002; 101:353-359.

124. Cubas R, Zhang S, Li M, Chen C, Yao Q. Chimeric Trop2 virus-like particles: a potential immunotherapeutic approach against pancreatic cancer. J Immunother. 2011; 34:251-263.

125. Bignotti E, Ravaggi A, Romani C, Falchetti M, Lonardi S, Facchetti F, Pecorelli S, Varughese J, Cocco E, Bellone S, Schwartz PE, Rutherford TJ, Santin AD. Trop-2 overexpression in poorly differentiated endometrial endometrioid carcinoma: implications for immunotherapy with hRS7, a humanized anti-trop-2 monoclonal antibody. Int J Gynecol Cancer. 2011; 21:1613-1621.
126. Raji R, Guzzo F, Carrara L, Varughese J, Cocco E, Bellone S, Betti M, Todeschini P, Gasparrini S, Ratner E, Silasi DA, Azodi M, Schwartz P, et al. Uterine and ovarian carcinosarcomas overexpressing Trop-2 are sensitive to hRS7, a humanized anti-Trop-2 antibody. J Exp Clin Cancer Res. 2011; 30:106.

127. Varughese J, Cocco E, Bellone S, de Leon M, Bellone M, Todeschini P, Schwartz PE, Rutherford TJ, Pecorelli S, Santin AD. Uterine serous papillary carcinomas overexpress human trophoblast-cell-surface marker (Trop-2) and are highly sensitive to immunotherapy with hRS7, a humanized antiTrop-2 monoclonal antibody. Cancer. 2011; 117:3163-3172.

128. Schneck H, Gierke B, Uppenkamp F, Behrens B, Niederacher D, Stoecklein NH, Templin MF, Pawlak M, Fehm T, Neubauer H. EpCAM-independent enrichment of circulating tumor cells in metastatic breast cancer. PLoS One. 2015; 10:e0144535.

129. Xu Y, Villalona-Calero MA. Irinotecan: mechanisms of tumor resistance and novel strategies for modulating its activity. Ann Oncol. 2002; 13:1841-1851.

130. Kawabata S, Oka M, Shiozawa K, Tsukamoto K, Nakatomi K, Soda H, Fukuda M, Ikegami Y, Sugahara K, Yamada Y, Kamihira $\mathrm{S}$, Doyle LA, Ross DD, et al. Breast cancer resistance protein directly confers SN-38 resistance of lung cancer cells. Biochem Biophys Res Commun. 2001; 280:1216-1223.

131. Chang CH, Wang Y, Zalath M, Liu D, Cardillo TM, Goldenberg DM. Combining ABCG2 inhibitors with IMMU-132, an anti-Trop-2 antibody conjugate of SN-38, overcomes resistance to SN-38 in breast and gastric cancers. Mol Cancer Ther. 2016; 15:1910-1919.

132. Cardillo TM, Sharkey RM, Rossi DL, Arrojo R, Mostafa AA, Goldenberg DM. Synthetic lethality exploitation by an anti-Trop-2-SN-38 antibody-drug conjugate, IMMU-132, plus PARP inhibitors in BRCA1/2-wild-type triple-negative breast cancer. Clin Cancer Res. 2017; 23:3405-3415.

133. Liu T, Tian J, Chen Z, Liang Y, Liu J, Liu S, Li H, Zhan J, Yang X. Anti-TROP2 conjugated hollow gold nanospheres as a novel nanostructure for targeted photothermal destruction of cervical cancer cells. Nanotechnology. 2014; 25:345103.

134. Redlich N, Robinson AM, Nickel KP, Stein AP, Wheeler DL, Adkins DR, Uppaluri R, Kimple RJ, Van Tine BA, Michel LS. Anti-Trop2 blockade enhances the therapeutic efficacy of ErbB3 inhibition in head and neck squamous cell carcinoma. Cell Death Dis. 2018; 9:5.

135. Bardia A, Tolaney SM, Juric D, Mayer IA, Vahdat LT, Diamond JR, Kalinsky K, O’Shaughnessy J, Moroose RL, Wahskowitz S, Sharkey RM, Wegener WA, Goldenberg DM. Efficacy of sacituzumab govitecan (anti-Trop-2-SN-38 antibody-drug conjugate) for endocrine-refractory hormonereceptor positive $(\mathrm{HR}+)$ metastatic breast cancer $(\mathrm{mBC}) . \mathrm{J}$ Clin Oncol. 2018; 36:1004. 